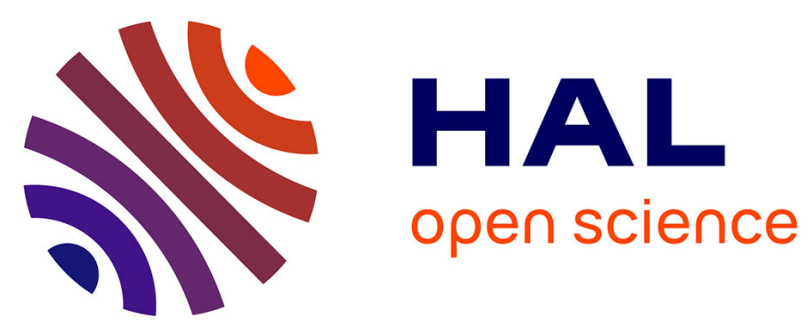

\title{
Simulation of carbon monoxide redistribution over central Africa during biomass burning events (Experiment for Regional Sources and Sinks of Oxidants (EXPRESSO))
}

\author{
S. Cautenet, D. Poulet, Claire Delon, Robert Delmas, J.-M. Grégoire, J. \\ Pereira, S. Cherchali, O. Amram, G. Flouzat
}

\section{To cite this version:}

S. Cautenet, D. Poulet, Claire Delon, Robert Delmas, J.-M. Grégoire, et al.. Simulation of carbon monoxide redistribution over central Africa during biomass burning events (Experiment for Regional Sources and Sinks of Oxidants (EXPRESSO)). Journal of Geophysical Research: Atmospheres, 1999, 104 (D23), pp.30641-30657. 10.1029/1999JD900393 . hal-02063356

\section{HAL Id: hal-02063356 \\ https://hal.uca.fr/hal-02063356}

Submitted on 25 Jan 2021

HAL is a multi-disciplinary open access archive for the deposit and dissemination of scientific research documents, whether they are published or not. The documents may come from teaching and research institutions in France or abroad, or from public or private research centers.
L'archive ouverte pluridisciplinaire HAL, est destinée au dépôt et à la diffusion de documents scientifiques de niveau recherche, publiés ou non, émanant des établissements d'enseignement et de recherche français ou étrangers, des laboratoires publics ou privés. 


\title{
Simulation of carbon monoxide redistribution over central Africa during biomass burning events (Experiment for Regional Sources and Sinks of Oxidants (EXPRESSO))
}

\author{
S. Cautenet, ${ }^{1}$ D. Poulet, ${ }^{1}$ C. Delon, ${ }^{2}$ R. Delmas, ${ }^{2}$ J.-M. Grégoire, ${ }^{3}$ \\ J. M. Pereira, ${ }^{4}$ S. Cherchali, ${ }^{5}$ O. Amram, ${ }^{5}$ and G. Flouzat ${ }^{5}$
}

\begin{abstract}
The Regional Atmospheric Modeling System (RAMS) is used to assess a realistic estimate of emissions by savanna fires from NOAA advanced very high resolution radiometer (AVHRR) satellite imagery during the Experiment for Regional Sources and Sinks of Oxidants (EXPRESSO) campaign. The daily amounts of gases released by biomass burning depend on burnt biomaterial, the mass of which is estimated from two independent methods: classification of vegetation formations (CV) or net primary productivity (NPP). The area of the burnt zone is derived from satellite imagery. The percent of burnt biomass or combustion factor $(\alpha)$ is determined by an adjustment procedure using two model runs and assumed to be $40 \%$, a value consistent with the biomass wetness. The simulated $\mathrm{CO}$ redistribution is compared with aircraft measurements (tracks and profiles). Two events of 4 and 5 days are examined, where flights above forest and savanna zones have been performed. In this study we show that the main mechanisms of the chemical species spatial redistribution originates from mesoscale features. The RAMS results are in rather good agreement with the aircraft measurements (vertical profiles or horizontal legs) over forest and savanna. The difference between the $\mathrm{CO}$ simulated fields obtained from CV or NPP is weak (about $20 \%$ or $30 \%$ ), and it is difficult to discriminate the best method because this difference is generally inferior to the gap between model and observations. One may consider this study as a preliminary approach to improve the estimate of released gases by biomass burning with the help of mesoscale modeling and the knowledge of the real sources.
\end{abstract}

\section{Introduction}

In recent years, evidence has begun to accumulate indicating that emissions from biomass burning are a dominant perturbation of atmospheric chemistry in the tropics, with a significant impact on the Earth's climate [Crutzen and Andreae, 1990; Levine, 1991; Delmas et al., 1991]. Most vegetation fires take place in tropical and equatorial regions, and there are strong seasonal variations in the extent and frequency of the savanna fires. In Africa (where half of the world's savanna biome is located [Andreae, 1991]), biomass burning plays an important role in the enhancement of the atmospheric greenhouse gases such as $\mathrm{CO}_{2}, \mathrm{CH}_{4}$, or ozone in the free troposphere [ $\mathrm{Ra}$ manathan et al., 1985; Cofer et al., 1990, 1996]. Large amounts of chemical compounds emitted by fires are distributed along the Intertropical Convergence Zone (ITCZ) on both sides during the dry seasons. From November to March the fire area

\footnotetext{
${ }^{1}$ Laboratoire de Météorologie Physique/OPGC, CNRS and Université Blaise Pascal, Aubière, France.

${ }^{2}$ Laboratoire de'Aèrologie/OMP, CNRS and Université Paul Sabatier, Toulouse, France.

${ }^{3}$ Space Applications Institute, Global Vegetation Monitoring, Joint Research Center, Ispra, Italy.

${ }^{4}$ Department of Forestry, Universidade Tecnica Lisboa, Lisbon.

${ }^{5}$ Centre d'Etudes Spatiales de la Biosphère, Unité Mixte de Recherche Centre National d'Etudes Spatiales, Université Paul Sabatier, CNRS, Toulouse, France.

Copyright 1999 by the American Geophysical Union.

Paper number 1999JD900393.

0148-0227/99/1999JD900393\$09.00
}

covers west and central Africa (Northern Hemisphere), but from July to October the fires are located in southern and east Africa (Southern Hemisphere). The aerosols and trace gases emitted by fires are transported above the central equatorial Atlantic. Many investigators have shown the role of large-scale circulations and convective transport in bringing these trace gases from sources to this accumulation zone [Chatfield et al., 1996; Krishnamurti et al., 1996; Pickering et al., 1996; Wang et al., 1996; Browell et al., 1996; Fishman et al., 1990, 1992, 1996; Garstang et al., 1996; Thompson et al., 1996].

Previous experiments (Fire of Savanna (FOS)/Dynamique et Chimie Atmosphérique en Forêt Equatorial (DECAFE) in 1991 and the Southern African Fire-Atmosphere Research Initiative (SAFARI) in 1992) have helped to characterize the burnt biomass, the fire behavior, and the emissions from African savanna fires [Menaut et al., 1991; Delmas et al., 1991; Scholes et al., 1996; Stocks et al., 1996; Trollope et al., 1996]. They showed that during the dry season, the regional scale photochemistry is basically regulated by biomass burning emissions.

During the Experiment for Regional Sources and Sinks of Oxidants (EXPRESSO) campaign, conducted in November and December 1996, aircraft measurements of atmospheric chemistry and meteorological parameters have been achieved. These data are associated with remote sensing imagery of the fire pattern. The aircraft data have been collected far from the main burning areas, at distances ranging between 200 and 500 $\mathrm{km}$ south of the region where intense savanna fires occur (central Cameroon and Central African Republic, southern Chad, northeast Central African Republic and southern Su- 


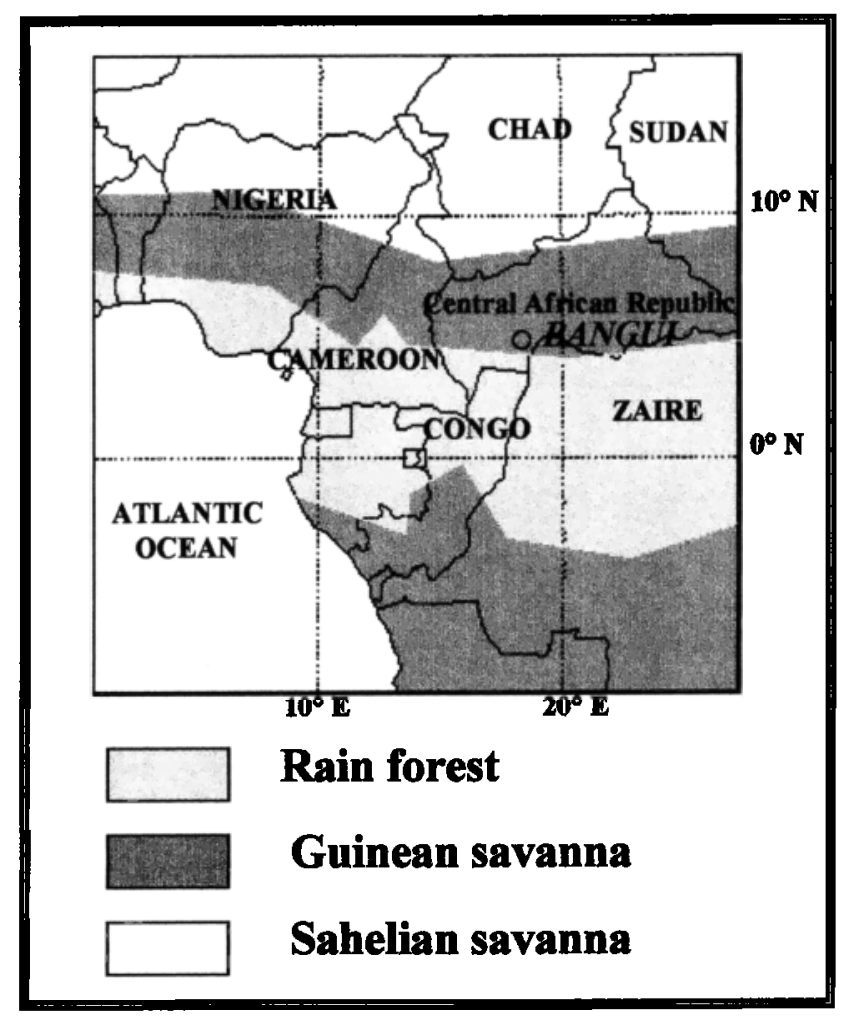

Figure 1. Location of countries and vegetal cover in central Africa: rain forest and Guinean and Sudanian savannas.

dan, Figure 1), with a view to checking the redistribution of pollutants near the ITCZ above moist savanna or forest cover.

Since photochemistry in the lower atmosphere is primarily driven by the sources of reactive trace compounds, in our study the first requirement is to get a realistic estimate of emissions by savanna fires. This is done through the detection and mapping of burnt surfaces using daily acquisition of NOAA advanced very high resolution radiometer (AVHRR) satellite pictures and the after-imagery of burnt surface characteristics [Pereira, 1999; Pereira et al., this issue]. Maps of burnt areas with a resolution of $0.25^{\circ} \times 0.25^{\circ}$ are converted into trace gas flux maps through empirical relationships, taking into account aboveground vegetation exposed to fires, combustion completeness, and emission factors. Large uncertainties affect most of these terms. These formulae originate from previous campaigns. The main aim of this modeling work is to assess the relevance of these relationships using a chemical tracer, carbon monoxide, assumed to be stable during its transport throughout the experimental domain. We use the Regional Atmospheric Modeling System (RAMS) [Pielke et al., 1992]) mesoscale model in its nonhydrostatic version coupled with a $\mathrm{CO}$ emission module. We run the model with two nested grids. Two events, which have substantially different meteorological contexts, have been simulated: one from November 23 to 26 , the other from November 28 to December 2. For the meteorological fields over central Africa and for the CO concentration field, the model validation is based upon experimental data sampled during flights over two ecosystems: Guinean savanna and forest. All the flights are located south of the ITCZ: for the first event, far from the ITCZ; for the second, in close proximity to the ITCZ.

This paper presents first the methods of evaluation of the
CO fluxes from daily maps of burnt areas. Then we show (1) a general overview of the meteorological conditions over central Africa during EXPRESSO, during the dry season, based on numerical results in the large grid; and (2) a mesoscale study with the fine grid, which highlights the main mechanisms of the chemical species' spatial redistribution: organized convergence/divergence zones localized along the ITCZ over central Africa, horizontal exchanges between savanna and forest ecosystems, and vertical transport from the boundary layer to the free troposphere. We examine the redistribution of $\mathrm{CO}$ fields, and we compare them with aircraft observations. Finally, this numerical method enables us to provide a first approach for checking the previous estimated $\mathrm{CO}$ fluxes from savanna fires in central Africa which will be applied to all trace gas fluxes having a significant impact on regional scale photochemistry.

\section{Vegetation Fire Studies}

Satellite remote sensing is the only technology that allows consistent data collection of the spatial and temporal distribution of fires at the scale required by the EXPRESSO experiment.

A portable monitoring system was developed and operated, in collaboration with the Institut Français de Recherche Scientifique pour le Développement en Coopération (ORSTOM) and the National Research Institute (NRI), in central Africa for the in situ, real-time acquisition and processing of NOAA AVHRR imagery [Janodet et al., 1996; Grégoire et al., this issue]. The acquisitions were initiated on October 1, 1996 and ended on December 2. One AVHRR scene per day was processed in situ to locate active fires and burnt areas within a region of $1,600,000 \mathrm{~km}^{2}$, centered on the Central African Republic $\left(4^{\circ}-12^{\circ} \mathrm{N}, 8^{\circ}-28^{\circ} \mathrm{E}\right)$. The detection of the image pixels containing one or more active fires was done using the contextual algorithm of Flasse and Cecatto [1996] applied to the visible, infrared, and thermal infrared channels of NOAA AVHRR images. Mapping of burnt areas was performed using the method developed by Pereira [1999], which discriminates burnt surfaces using three types of spectral information: (1) the GEMI3 spectral index, a modified version of the global environmental monitoring index (GEMI) [Pinty and Verstraete, 1992]; (2) the reflectance values of channels 1 and 2 of AVHRR; and (3) the reflective part of the response in AVHRR channel 3. From the daily fire maps, temporal composites were done (Figure 2), as well as an analysis of fire distribution by vegetation type within the EXPRESSO study area. A detailed analysis of fire occurrence during the month of November 1996 is presented by Pereira et al. [this issue] and Grégoire et al. [this issue]. According to these authors the main causes of error are significant cloudiness, radiometric noise, and an incomplete satellite coverage of the area under study. They derive a burnt area which therefore can be underestimated in some instances because of an extensive cloud cover; on the other hand, the next days are overestimated as they are assigned the burnt surfaces not retrieved during the previous period. Thus the daily burnt area (Figure 3 ) shows large variation and can double from day to day. However, when cumulated over a 4- or 5-day event, their estimate of the total burnt area is accurate ( $\pm 15 \%$ approximately [Pereira et al., this issue]) because during the dry season the cloud cover is not persistent. In our modeling study we cannot accurately reconstruct the true spatiotemporal distribution of fires, which could 


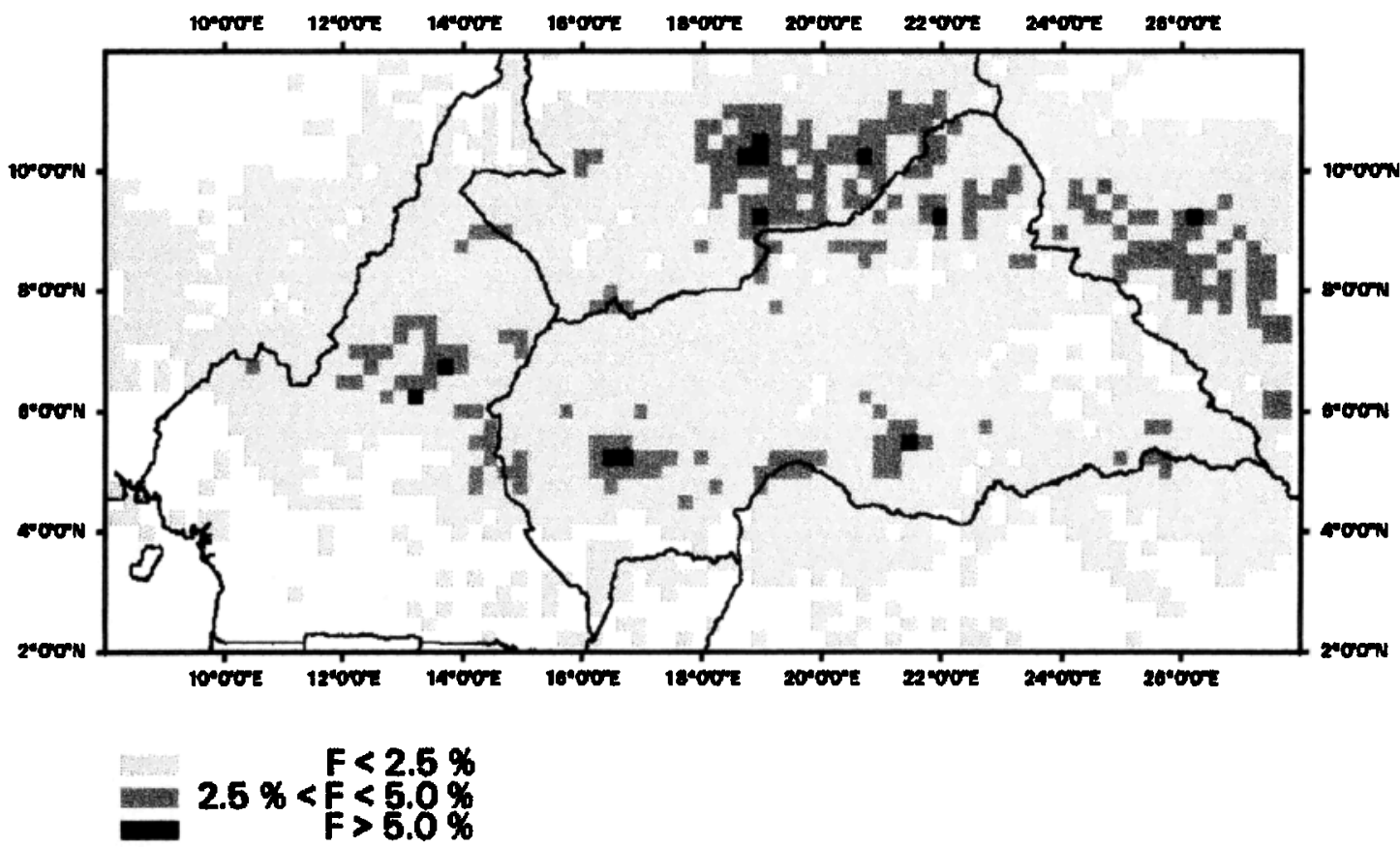

Figure 2. Detection of active fires during the dry season field experiment: percentage of AVHRR pixels detected as fire pixels in each $0.25^{\circ} \times 0.25^{\circ}$ cell for 25 days (October 31 through December 2, 1996) [Pereira et al., this issue; Grégoire et al., this issue].

be the origin of some discrepancies. We have to keep this in mind when analyzing our results.

\section{Estimate of $\mathrm{CO}$ Fluxes}

Fire is a regular phenomenon in savanna regions, which occurs each winter during the dry season in central Africa. The herbaceous mass in savannas ranges from $1000 \mathrm{~kg} \mathrm{ha}^{-1}$ in semiarid areas to $7000 \mathrm{~kg} \mathrm{ha}^{-1}$ over optimum sites. Moist savannas have high levels of herbaceous productivity, with annual production values of up to $4800 \mathrm{~kg} \mathrm{ha}^{-1}$ for central African miombo [Rutherford, 1978]. However, the wet savanna ( $80 \%$ of moisture) in Lamto (west Africa) exhibits a mass of dry matter of 8000 to $9000 \mathrm{~kg} \mathrm{ha}^{-1}$ [Lacaux et al., 1993, 1995].

The emission of any gaseous or particulate compound from biomass burning depends on two parameters: the amount of biomaterial burnt and the emission factor (EF), which represents the proportion of a given compound released during the combustion. For regional flux determination, in which the amount of biomass burnt can be estimated, the simplest approach is based on an equation such as

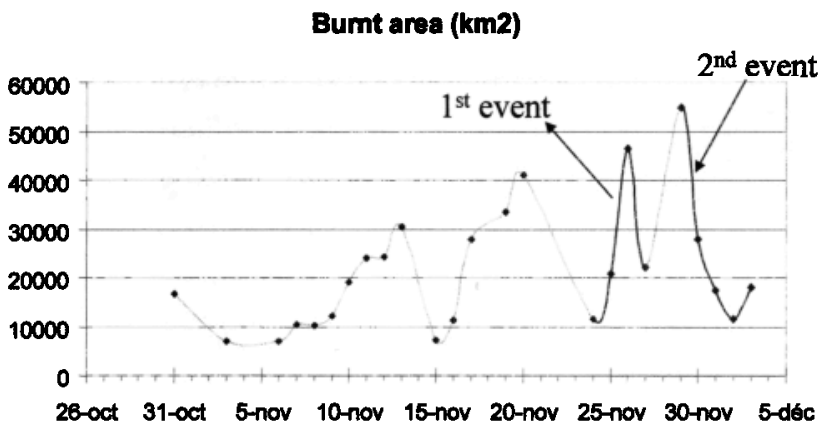

Figure 3. Daily burnt area time series.

$$
\Phi[X]=B \alpha \mathrm{EF}[X]
$$

where $\Phi[X]$ represents the emission flux of the compound $X$, $B$ is the biomass exposed to fire $\left(\mathrm{kg} \mathrm{m}^{-2}\right), \alpha$ is the fraction of the biomass which is actually burnt (also called combustion factor), and $\mathrm{EF}[X]$ is the emission factor of the compound $X$ ( $\mathrm{g} \mathrm{kg}^{-1} \mathrm{dry}$ fuel). Each of these terms depends on vegetational composition, environmental conditions, land use patterns, and fire regimes (ignition potential, fire behavior). These factors influence the quantity and the distribution of emission chemistry. Finally, large uncertainties exist on each term of (1) which we will examine in the next sections.

\subsection{Biomass Exposed to Fire}

Two independent methods to estimate the biomass density are used in this study. The first evaluates the biomass from classification of vegetation according to a vegetation types map [Pereira et al., this issue], hereafter referred to as CV; the second evaluates the biomass from net primary productivity or NPP.

For CV the biomass density is obtained from the literature. Maxima and minima biomass density values were taken into account because these vegetation types present a high interannual variability. The values for the Sudanian savanna range between 2 and $4 \mathrm{t} \mathrm{ha}^{-1}$ [Menaut et al., 1991]; those for Guinean savanna range between 3.6 and $7.9 \mathrm{t} \mathrm{ha}^{-1}$ according to data from the Oak Ridge National Laboratory Distributed Active Archive Center (ORNL DAAC) data base (available at http:// www.eosdis.ornl.gov/npp/npp_home.html, 1998). For dense forest the minimum and maximum values range between 94 and $457 \mathrm{t} \mathrm{ha}^{-1}$ [Brown and Gaston, 1996].

For the second method (NPP) the biomass density is obtained by a new approach. The methodology for this estimation of biomass exposed to fire at regional scale is based on a functional classification of the vegetation formations estab- 


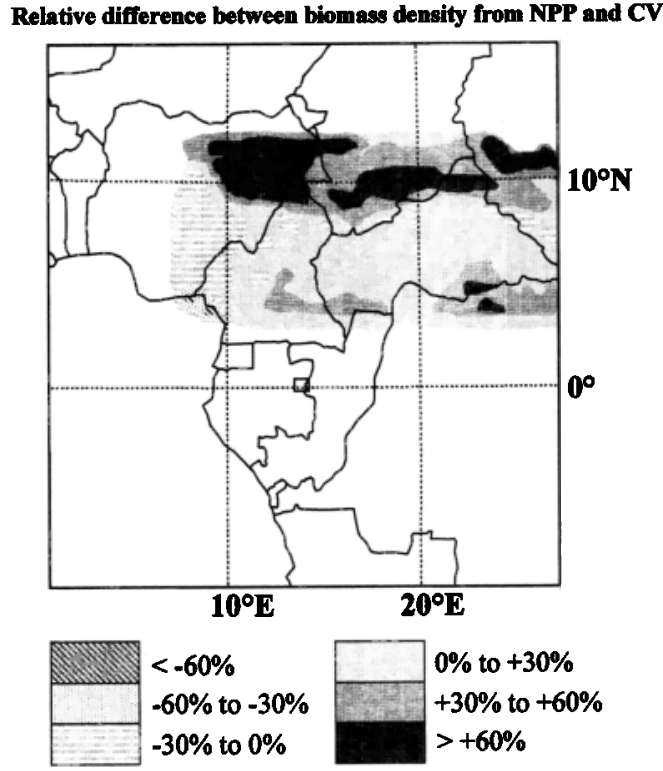

Figure 4. Difference between assessment of biomass density from net primary productivity (NPP) and classification of vegetation formations (CV) (NPP biomass density - CV biomass density). These values are averaged on cells of $60 \mathrm{~km} \times 60 \mathrm{~km}$.

lished from NOAA AVHRR data with resolution of $8 \mathrm{~km}$ in space and 10 days in time over a period of 11 years (1983 to 1993). Time series analysis techniques provide an opportunity to identify and describe coherent structures in the observation using few parameters. The approach used merges those objects that have similar temporal behaviors. This clustering model allows analysis of the phenological behavior of the terrestrial surface at small scale. The map obtained accounts for the mean annual functioning of the vegetation and for the interannual variability of the vegetation formations.

Then a model [Kumar and Monteith, 1982] is used to estimate regional net primary productivity (NPP). The model assumes a decomposition of NPP into independent parameters such as incident solar radiation, radiation absorption efficiency by canopies $\varepsilon_{i}$, and conversion efficiency of absorbed radiation into organic dry matter $\varepsilon_{b}$. A similar approach has already been used for the estimation of the terrestrial biosphere NPP by Heimann and Keeling [1989] and Ruimy et al. [1994], but the precision for some of the input parameters has been greatly improved, as recommended by Ruimy et al. [1994], compared to previous uses of this model on a regional or global scale. The radiation absorption efficiency $\varepsilon_{i}$ has been derived from the time series classification profiles for each vegetation class using the time evolution of the normalized difference vegetation index (NDVI) cycle (obtained in the previous step above). The $\varepsilon_{b}$ vegetation map is established from NDVI time series classifications which take into account the interannual variation in vegetation cover and from the distinction between trees and herbaceous species. Better biomass estimates are obtained. However, the estimation of biomass density is difficult, and the total error can reach $80 \%$ in some cases. Figure 4 shows the difference between the biomass density as evaluated from $\mathrm{CV}$ and NPP. The average variation is about $30 \%$ between the two methods, and the values are generally higher (positive difference) for NPP than CV except for Guinean savanna in Nigeria. We note that the higher values are found in Guinean more than in Sudanian savannas.

\subsection{Combustion Factor ( $\alpha$ )}

The combustion factor $(\alpha)$ determines the ratio of burnt to total biomass in the field. It is a direct function of fuel moisture which varies according to plant species and as a function of time during the dry season. Early fires ignite the fairly humid grass cover with difficulty and burn only $20-25 \%$ of the grass cover. Middle to late fire destroys most of the herbaceous biomass (up to $100 \%$ ); however, due to spatial heterogeneity only $65-95 \%$ of the biomass is consumed on average in humid savanna [Menaut et al., 1991]. Large variations were observed in the SAFARI campaign where $98 \%$ of available grass fuels, but only $32 \%$ of downed and dead woody fuels, were consumed [Shea et al., 1996].

Giving, a priori, an average value to $\alpha$ is somewhat speculative since the grass cover moisture is not homogeneous over the entire savanna region, and varies all along the campaign. During the EXPRESSO campaign the fires mainly took place over Guinean savanna where grass and woods often are mixed. The $\alpha$ value may range from almost 1 (dry biomass) to much lower values (wet vegetation). This point will be discussed in section 4.

\subsection{Emission Factor}

The emission factor is generally calculated by reference to $\mathrm{CO}_{2}$ on the basis of the experimental emission ratio: $\mathrm{ER}=$ $\Delta[X] / \Delta\left[\mathrm{CO}_{2}\right]$ corresponding to the excesses of these two constituents in the fire plume compared with the average concentration in ambient air. The emission factor is derived from the emission ratio ER using the carbon mass balance method, since the amount of carbon in the biomass material (around $45 \%$ ) presents little variation and most of the carbonaceous species can be measured [Delmas et al., 1995]. The emission ratio is highly dependent on the type of combustion, especially the relative importance of the two main phases of the combustion, flaming and smoldering. Whatever the combustion phase, the main compound emitted is $\mathrm{CO}_{2}$, which represents between $85 \%$ and $90 \%$ of the carbon released into the atmosphere [Lobert et al., 1991].

Three complete data sets were obtained during prescribed savanna fires in Australia [Hurst et al., 1994a, b], the FOS/ DECAFE experiment on the Ivory Coast [Lacaux et al., 1993, 1995] and the SAFARI campaign in South Africa [Cofer et al., 1996; Andreae et al., 1996a, and references therein].

The most recent data set obtained during the SAFARI campaign is certainly the most complete as it concerns measurements carried out by several groups in different ecosystems. $\Delta \mathrm{CO} / \Delta \mathrm{CO}_{2}(\mathrm{~mol} \%)$ ratios measured in the various ecosystems range from $3.5 \pm 1.0$ in semiarid savanna in Zimbabwe [ $L e$ Canut et al., 1996] to $9.4 \pm 1.3$ in a mixed forest-shrub area in the humid mountain area of Natal, South Africa [Koppmann et $a l ., 1996]$. The average $\Delta \mathrm{CO} / \Delta \mathrm{CO}_{2}$ ratio is a good indicator of the quality of the combustion, low values being associated with intense flaming conditions. An average value of $6.2 \%$ is considered as representative of $\mathrm{CO}$ emission ratios for average savanna fires [Andreae et al., 1996a]. Using this value and the carbon mass balance method, we come up with an average emission factor of $65 \mathrm{~g}(\mathrm{CO}) / \mathrm{kg}$ of dry matter for savannas and $230 \mathrm{~g} \mathrm{(CO)} / \mathrm{kg}$ of dry matter for forests.

During the EXPRESSO campaign the observed domain had an area equal to $1,970,000 \mathrm{~km}^{2},\left(12^{\circ} \mathrm{N}\right.$ to $4^{\circ} \mathrm{N}$ in latitude and $8^{\circ} \mathrm{E}$ to $28^{\circ} \mathrm{E}$ in longitude). Between October 31 and December 2,1996 , an area of $514,000 \mathrm{~km}^{2}$ was burnt. The relationship (1) (with $\alpha_{\mathrm{sav}}=0.8, \alpha_{\mathrm{for}}=0.25, \mathrm{EF}(\mathrm{CO})_{\mathrm{sav}}=65 \mathrm{~g} / \mathrm{kg}$, and EF- 
(a)
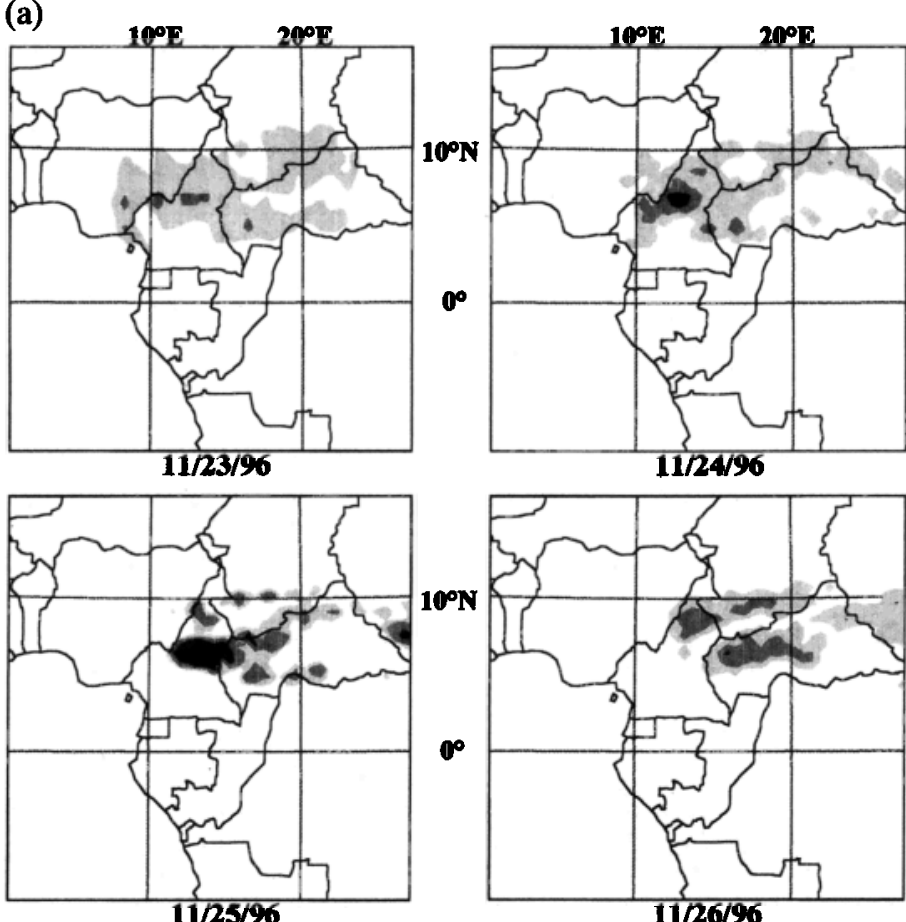

CO surface emission (kg ha-1 d-1)

0 to 15

15 to 45

45 and more

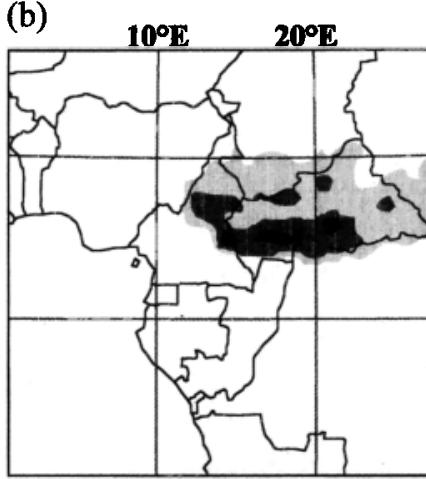

11/28/96

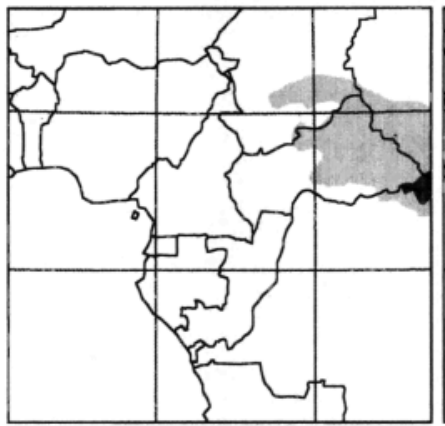

$12 / 01 / 96$

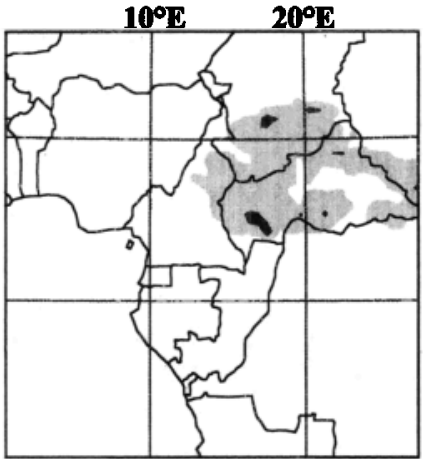

$11 / 29 / 96$

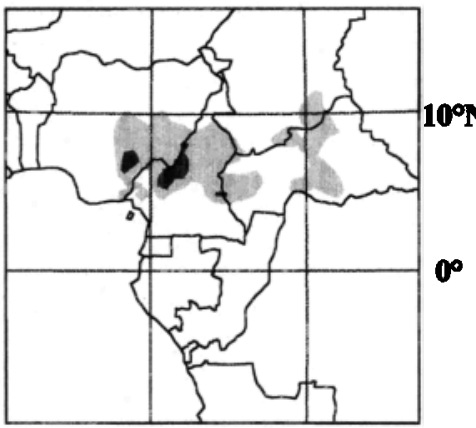

12/02/96

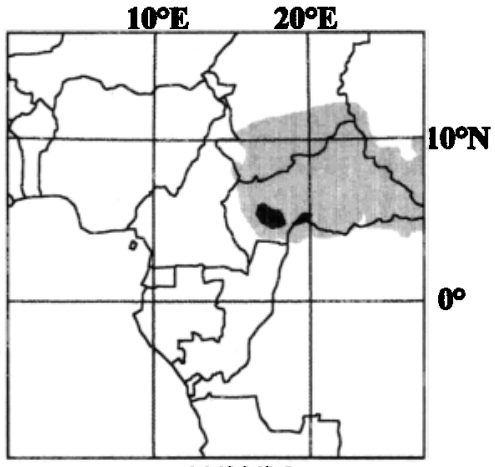

$11 / 30 / 96$

\section{CO flux (kg.ha-1 day $\left.{ }^{-1}\right)$}

0 to 20

20 to 60

60 and more

Figure 5. Emitted carbon monoxide fluxes at the surface for (a) November 23, 24, 25, and 26, 1996, and (b) November 28,29, and 30, and December 1 and 2. These fluxes are calculated from the CV method with $\alpha_{\text {sav }}=$ 0.8 . They are averaged on cells of $60 \mathrm{~km} \times 60 \mathrm{~km}$.

$(\mathrm{CO})_{\text {for }}=230 \mathrm{~g} / \mathrm{kg}$ ) gives $16 \mathrm{Mt}$ of $\mathrm{CO}$ emitted during this period, that is, $313 \mathrm{~kg} \mathrm{ha}^{-1}$ of burnt area. These values are more important than those obtained in the SAFARI experiment, where an average value of $200 \mathrm{~kg} \mathrm{ha}^{-1}$ was found.
Figures $5 \mathrm{a}$ and $5 \mathrm{~b}$ exhibit the $\mathrm{CO}$ emission fluxes averaged on grid 1 (cells equal to $60 \mathrm{~km} \times 60 \mathrm{~km}$ ), for the 4-day event from November 23 to 26, 1996 (first event, Figure 5a) and for the 5-day event from November 28 to December 2 (second 


\section{EXPRESSO}

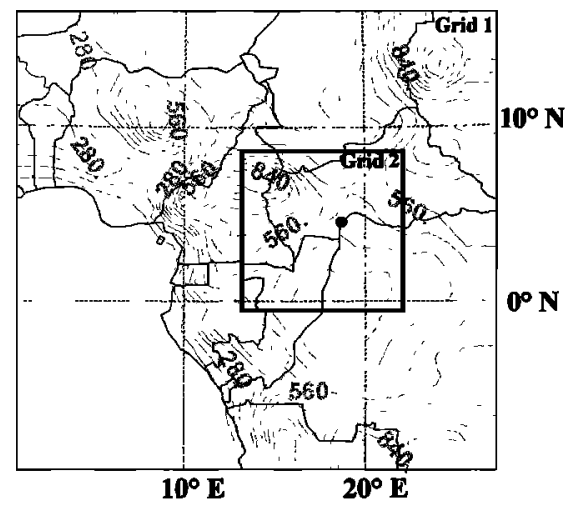

Figure 6. Topography in meters and two nested grids in the simulated domain. The coarse grid (or grid 1) has 50 grid points with spacing of $60 \mathrm{~km}$, and the fine grid (or grid 2) has 50 grid points with spacing of $20 \mathrm{~km}$.

event, Figure 5b). There is a maximum in central Cameroon on November 25 and in the Central African Republic on December 28 . Some values are very high, for example, $144 \mathrm{~kg} \mathrm{ha}^{-1}$ $\mathrm{d}^{-1}$ (cell of $60 \mathrm{~km} \times 60 \mathrm{~km}$ ) where the unburnt regions are mixed with burnt ones. For the second event the emissions are more extended and more intense than the first. We remark that for both studied events (1) the surface emission shifts eastward day by day and (2) the daily intensity of $\mathrm{CO}$ flux vanes strongly from one day to the next by a factor of 3 due to the remote sensing method. Every day, more or less intense fires are located in the north of the EXPRESSO domain, about $200-500 \mathrm{~km}$ from aircraft observations.

\section{Numerical Model}

Our modeling task is based upon the regional atmospheric modeling system (RAMS) code [Pielke et al., 1992]. RAMS is a primitive equation prognostic model developed for the simulation and forecasting of weather systems. This model runs using the nonhydrostatic option. The cloud convection model included in RAMS is the explicit scheme of Tripoli and Cotton [1982]. The model predicts soil temperature and moisture from the prognostic soil model [Tremback and Kessler, 1985], which takes into account the vegetation cover and the type of soil according to Avissar and Pielke's [1989] model. Many previous investigations on regional pollution have made use of RAMS [Lyons et al., 1995; Millan et al., 1997; Edy and Cautenet, 1998].

The simulated domain exhibits three classes: rain forest, mixed forest/savanna (Guinean savanna or moist savanna), and Sudanian savanna or dry savanna (Figure 1). The topography (Figure 6) is available from the NOAA web site at http:// www.ngdc.noaa.gov/mgg/global. We can see that the relief is not negligible: Adamaoua Plateau is located in central Cameroon (grid 1) and in the northwestern Central African Republic (grid 2). The "wall on top" condition is used as a top boundary condition. The lateral boundary condition uses the Davies [1976] relaxation method to nudge the RAMS solution to the observations (European Centre for Medium-Range Weather Forecasts (ECMWF) data). The nudging is weighted at the five outermost points. The radiation scheme [Chen and Cotton, 1988] predicts the longwave and shortwave radiation tendencies. It includes the radiative effect of water vapor, ozone, and carbon dioxide. The turbulence scheme is the Smagorinsky deformation eddy viscosity described by Tripoli and Cotton [1982], where adjustments to the vertical exchange coefficients were made using a Richardson number/moist BruntVaisala frequency enhancement factor. The advection operator is the flux form of the sixth order for the horizontal advection and a forward form of the vertical advection [Tremback et al., 1987]. The time split scheme [Tremback et al., 1987] is used for the model time integration. In addition, RAMS has the capability to thoroughly describe the transport of passive scalars including three-dimensional (3-D) advection and turbulent diffusion. We use this option to study the CO transport.

The initialization is obtained from the 0000 UTC ECMWF data and from assimilation of the 0000 UTC Bangui $\left(4.23^{\circ} \mathrm{N}\right.$, $18.34^{\circ} \mathrm{E}$ ) soundings and surface data. A weak nudging of meteorological fields is carried out every 24 hours. The run begins at 0000 UTC on November 23 and ends at 2400 UTC on November 26 for the first event; it begins at 0000 UTC on November 28 and ends at 2400 UTC on December 2 for the second event. Two nested grids are used (Figure 6). The coarse grid (or grid 1) domain is bounded by $0^{\circ} \mathrm{E}$ to $30^{\circ} \mathrm{E}$ longitude, and $20^{\circ} \mathrm{N}$ to $10^{\circ} \mathrm{S}$ in latitude. This domain consists of 50 grid points in the $x$ direction and $\mathbf{5 0}$ grid points in the $y$ direction. The horizontal coarse grid spacing is $60 \mathrm{~km}$ in both the eastwest and north-south directions with 30 sigma- $z$ levels. The vertical grid spacing is $25 \mathrm{~m}$ near the ground, with a geometric stretch ratio of 1.2 and a maximum interval of $1000 \mathrm{~m}$ above $3000 \mathrm{~m}$ up to the model top. The geometric stretch ratio is used to provide a higher resolution close to ground. The time step used for grid 1 is $60 \mathrm{~s}$. The fine grid (hereafter named grid 2) is centered on Bangui $\left(4.23^{\circ} \mathrm{N}, 18.34^{\circ} \mathrm{E}\right)$ and illustrates the EXPRESSO region. There are also 50 points with a horizontal fine grid spacing of $20 \mathrm{~km}$ in both the $x$ and $y$ directions. The vertical spacing is the same as in the coarse grid. The two grids communicate with each other in a two-way scheme described by Clark and Farley [1984]. The nested grid allows a wider range of motion scales to be modeled simultaneously and interactively. The time step for grid 2 is $20 \mathrm{~s}$.

For estimating the planetary boundary layer and the mixing meteorological quantities in the lower troposphere, we investigated the realistic comprehensive surface heat flux over savanna and forest. The parameters for the soil and vegetation modules have been chosen so that latent and sensible heat fluxes in forest and in savanna are realistic with respect to observations (C. Delon et al., unpublished manuscript, 1999). Averaged sensible flux is $63 \mathrm{~W} \mathrm{~m}^{-2}$ in forest and $95 \mathrm{~W} \mathrm{~m}^{-2}$ in Sudanian savanna, while averaged latent flux is $350 \mathrm{~W} \mathrm{~m}^{-2}$ in forest and $240 \mathrm{~W} \mathrm{~m}^{-2}$ in savanna. The Bowen ratio is about 0.2 for forest and 0.4 for savanna. The modeled maxima values conform to measurements in a magnitude of $30 \%$.

The numerical model is coupled on-line with the emission module. For each cell, if the fire activity is detected by satellite, the daily burnt biomass density is evaluated according to the $\mathrm{CV}$ or NPP method. It depends on the burnt areas. Then, at each time, $\mathrm{CO}$ fluxes are estimated at any grid point following (1). CO emission is assumed to occur only during daytime and at a constant rate during 9 hours (from 1000 to 1900 UTC) [Moula et al., 1996; Menzel et al., 1991]. Runs with a variable rate (depending on sinusoidal time, with a maximum at 1500 UTC) have been performed, but the effect on $\mathrm{CO}$ redistribution is negligible. For each fire event, two runs are carricd out with two values for the savanna combustion factor: $\alpha=0.8$ for 

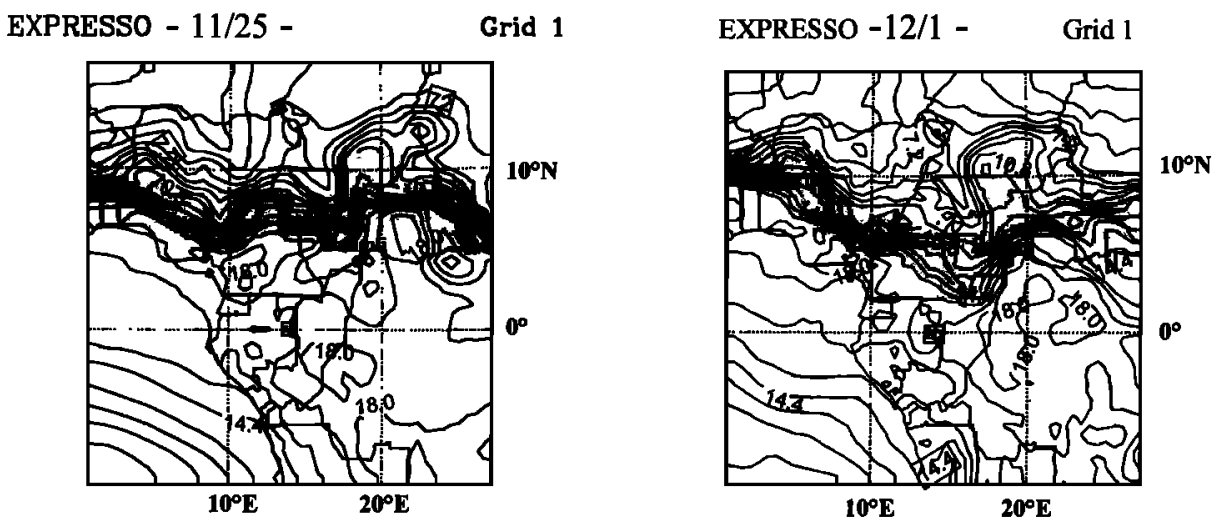

Figure 7. Horizontal mixing ratio of water vapor at $250 \mathrm{~m}$ in grid 1 for November 25 and for December 1 at 1200 UTC. Shading denotes the position of the ITCZ obtained from the strong horizontal gradient $(15 \mathrm{~g}$ $\mathrm{kg}^{-1}$ and $10 \mathrm{~g} \mathrm{~kg}^{-1}$ ). Close to Bangui, the observed values in aircraft measurements are $17 \mathrm{~g} \mathrm{~kg}^{-1}$ on November 25 and $15.2 \mathrm{~g} \mathrm{~kg}^{-1}$ on December 1 .

run $A$, and 0.4 for run $B$. The contribution of burning forest in CO flux is very small, so $\alpha_{\text {for }}$ may keep the same value for both runs $(0.25)$. These two values represent $100 \%$ of the variability of $\mathrm{CO}$ emission. This point needs to be highlighted here.

The choice of the $\alpha$ values may seem somewhat arbitrary. However, in previous sections, we have discussed the uncertainties associated with the various factors making up the $\mathrm{CO}$ flux: burnt area (100\%), biomass exposed to fire $(80 \%)$, and now $\alpha(100 \%)$. The emission factor is assumed to be known with a rather good accuracy and may be neglected in the present discussion. All these uncertainties lead us to use a tuning technique when running the model, rather than examining each term of the $\mathrm{CO}$ flux formula. The first run (or run A) with $\alpha=0.8$ for both events gives overestimates in $\mathrm{CO}$ concentrations (when compared with experimental data). The second run (or run $B$ ) with $\alpha=0.4$ is much more realistic for both events (all the other factors remain unchanged). The effect is to divide the CO flux by 2, so that any term (burnt area, biomass density, $\alpha$, or emission factor) could undergo this modification; however, it seems logical to divide $\alpha$ because the surface wetness precludes a complete burning and, also, $\alpha$ is the only parameter constant at any grid point.

In the fire areas a forcing of the air temperature equal to $3^{\circ} \mathrm{C}$ is performed so as to obtain a mean value about $1000 \mathrm{~m}$ for the convection column height above ground level. For dry savannas in the SAFARI experiment, Stocks et al. [1996] show that the convection column height above ground level varies between 500 and $2200 \mathrm{~m}$. For moist savanna the column is lower: During the EXPRESSO campaign, fires mainly burn the biomass of Guinean savanna, a moist savanna. For this reason, the dry convection column is weakly developed in the vertical.

The background concentration is assumed to be $200 \mathrm{ppb}$ in the boundary layer (below $1000 \mathrm{~m}$ ) and $100 \mathrm{ppb}$ above free troposphere because these are the smallest observed values in the EXPRESSO campaign. These are the model initial values.

\section{Large-Scale and Mesoscale Features}

Although the two modeled periods are very different as regards the ITCZ position (Figure 7), the large-scale mean flow patterns are typical of the dry season that dominated in the EXPRESSO period. In Figure 7, at $250 \mathrm{~m}$ above the surface, the water vapor mixing ratio exhibits a strong horizon- tal gradient: $18 \mathrm{~g} \mathrm{~kg}^{-1}$ at $10 \mathrm{~g} \mathrm{~kg}^{-1}$ for both days. On the meridian line of Bangui, the ITCZ falls between $7^{\circ} \mathrm{N}$ and $8^{\circ} \mathrm{N}$ for November 25 , and between $5^{\circ} \mathrm{N}$ and $6^{\circ} \mathrm{N}$ for November 30 . It separates two air masses: the dry air advected by Harmattan flow and the oceanic air from Monsoon flow. The surface air moisture near Bangui is relatively high $\left(17 \mathrm{~g} \mathrm{~kg}^{-1}\right)$ for the first event, and slightly lower $\left(15.4 \mathrm{~g} \mathrm{~kg}^{-1}\right)$ for the second. These results (position of ITCZ and humidity) agree with aircraft and surface measurements (C. Delon et al., unpublished manuscript, 1999).

The streamlines near the surface (Figure 8a) show that the flow is well established north of $10^{\circ} \mathrm{N}$ (Harmattan from northeast) and below the equator (Monsoon from south). Between $0^{\circ}$ and $10^{\circ} \mathrm{N}$, the structure is very complex and depends on ITCZ position. Convergence and divergence zones associated with recirculation regions alternate along the ITCZ characterized by the confluence of two flows. At $700 \mathrm{hPa}$, approximately $3 \mathrm{~km}$ above surface level (Figure $8 \mathrm{~b}$ ), the flow principally comes from east-northeast for both cases. In the middle of the troposphere, at $500 \mathrm{~h} \mathrm{~Pa}$, approximately $5.5 \mathrm{~km}$ above surface level, easterly winds greater than $10 \mathrm{~m} \mathrm{~s}^{-1}$ are well established for the entire domain.

The most outstanding feature is the strong wind shear, African Easterly Jet, between the lower and upper levels in the zone located near the ITCZ, with very weak winds (about 2 to $5 \mathrm{~m} \mathrm{~s}^{-1}$ ) in the boundary layer close to the ITCZ and strong winds (greater than $10 \mathrm{~m} \mathrm{~s}^{-1}$ ) in the free troposphere. In this type of simulation with two nested grids, not only are the large-scale fields described, but also the local circulations (valley and mountains or sea breezes, weak vegetation breeze between savanna and rain forest zones, cloud convection). These realistic dynamics contribute to give a better transport. In savanna regions the dry convection in the boundary layer is an important phenomenon. In the forest zone a shallow convection develops during afternoon (aircraft observations point out some stratocumulus clouds) and enhances the mixing processes within the boundary layer.

During the first event the vertical cross section of meridian winds at Bangui in grid 2 shows that the winds are weak $(2 \mathrm{~m}$ $\mathrm{s}^{-1}$ ) in the boundary layer inside Monsoon flow and higher (4 $\mathrm{m} \mathrm{s}^{-1}$ ) above savanna (Figure 9a). We note a zone with very weak surface winds, lower than $1 \mathrm{~m} \mathrm{~s}^{-1}$ close to Bangui $\left(4^{\circ} \mathrm{N}\right)$, 
Streamlines on grid 1 (11/25/96)


(a)
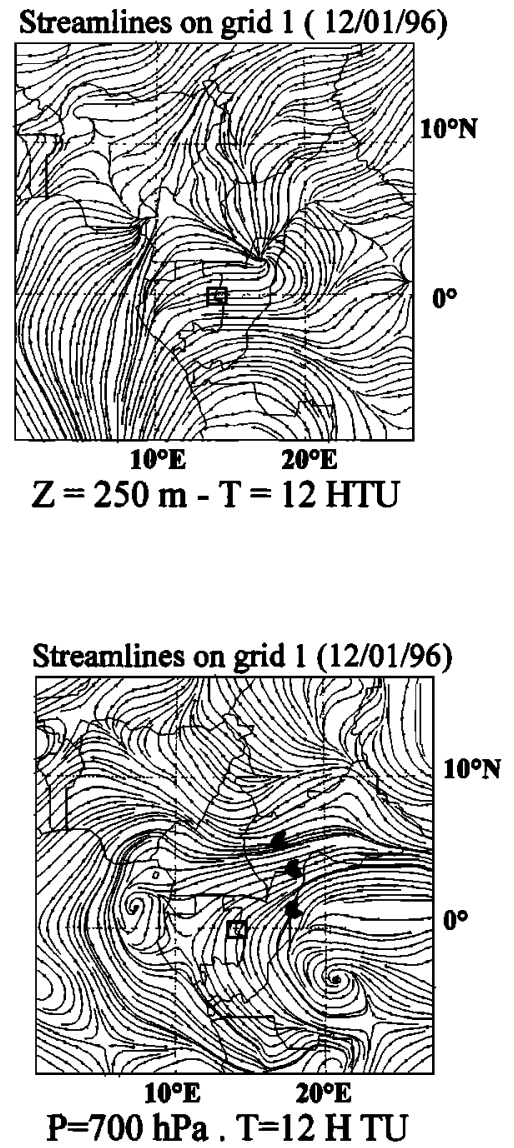

Figure 8. Streamlines in grid 1 (a) at $250 \mathrm{~m}$ and (b) at $700 \mathrm{hPa}$ in grid 1 , for November 25 and for December 1 at 1200 UTC.

which is connected to the divergence zone (Figure 9c) or the convergence zone (Figure 9d). However, between 2000 and $3000 \mathrm{~m}$ in the middle of grid 2 (Bangui), winds are stronger (Figures $9 \mathrm{a}$ and $9 \mathrm{~b}$ ). The eastern component is about 5 to $8 \mathrm{~m}$ $\mathrm{s}^{-1}$, which constitutes the African Eastern Jet (AEJ). In the vertical section of the zonal wind component, we note that the local effect of the topography $u$ is weakly positive in a globally negative Harmattan flow (Figure 9b). These results are in good agreement with the aircraft and sounding observations (Figure 10). The aircraft measurements above savanna or forest show that below $1000 \mathrm{~m}$, in the Monsoon flow, the wind is weak (1 $\left.\mathrm{m} \mathrm{s}^{-1}\right)$ and has a southwestern direction; above $1000 \mathrm{~m}$, in the Harmattan flow, the wind has a northeastern direction. At Bangui, the wind vector becomes regular above $3000 \mathrm{~m}(8 \mathrm{~m}$ $\left.\mathrm{s}^{-1}\right)$. At $3000 \mathrm{~m}$ in altitude, the winds are weaker over savanna than over forest (Figures 9a, 9b, and 10). During the second event the wind in the boundary layer over savanna is mainly north, whereas the direction is very variable over forest (Figure 10 ). During the second event the ITCZ position was very low in latitude and located near Bangui. Large differences in wind pattern are observed (grid 2): In particular, the area covered by wind with a southward component reaches far lower latitudes, about $5^{\circ} \mathrm{N}$, but only $8^{\circ} \mathrm{N}$ for the first event (Figures $9 \mathrm{c}$ and $9 \mathrm{~d}$ ). This is in agreement with observations (Figure 10).

This region is a convergence zone where strong updrafts develop (Figure 11). Although the region was under the Harmattan flow, the topography plays its role to raise the pollutants (Figure 11). These local features are significant in these meteorological situations where the wind is weak in the boundary layer.

In these cases of dry convection, we see that it is very important to simulate the divergence/convergence zones associated with the ITCZ (event 1 and event 2, respectively): This is the driving mechanism which pumps pollutants from lower levels up to free troposphere.

The vertical profiles of modeled potential temperature (Figure 12) exhibit some differences between, on one hand, savanna and rain forest regions, and fire zones on the other hand. We note a stronger instability near fires than in the Guinean savanna or the forest zone. In both cases, Guinean savanna and forest, the boundary layer is not very thick $(1200 \mathrm{~m})$. Above this layer, the troposphere is rather stable, which leads to weak vertical motions (some centimeters per second), of the same order as subsidence velocities. These features are confirmed by the observations during the EXPRESSO experiment (C. Delon et al., unpublished manuscript, 1999).

\section{Aircraft Tracks}

The aircraft involved in the EXPRESSO campaign was the French research aircraft Fokker 27 Avion de Recherche Atmosphérique et de Télédétection (ARAT). It measured the main meteorological and chemical parameters [Delmas et al., this issue]. Seven flights cover the two events we have modeled. Flights 45,46 , and 47 refer to the first event, whereas flights 50 , 51,52 , and 53 refer to the second event. We have drawn the 


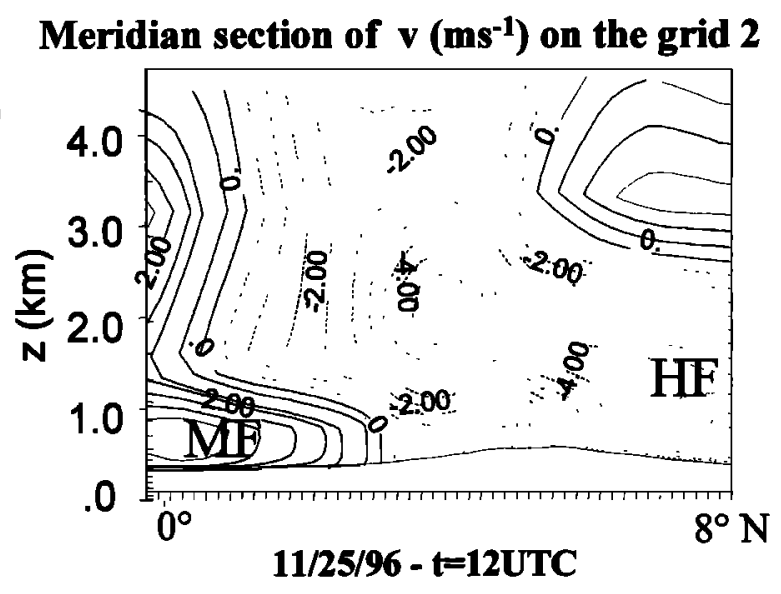

\section{Zonal section of $\mathbf{u}\left(\mathbf{m s}^{-1}\right) \quad$ Grid 2}

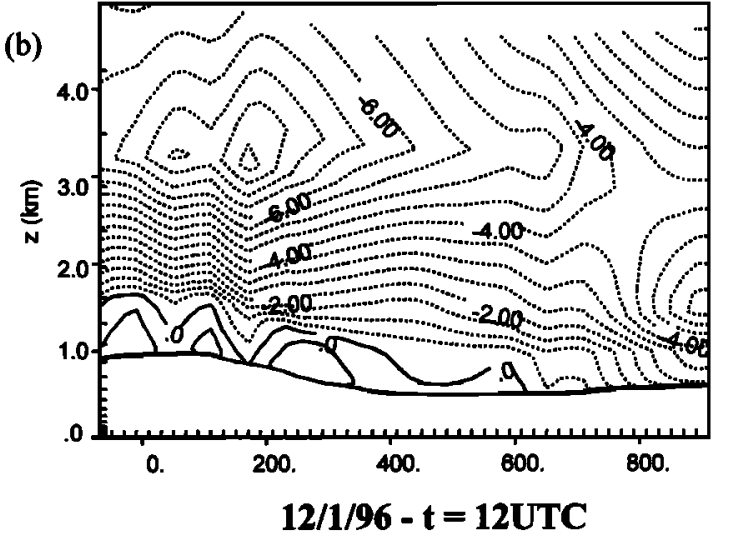

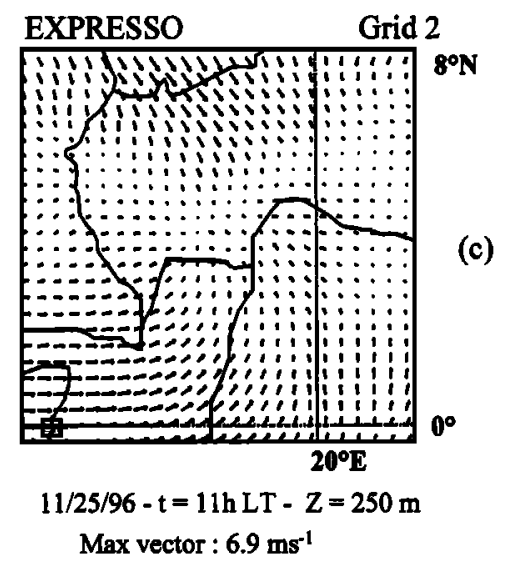

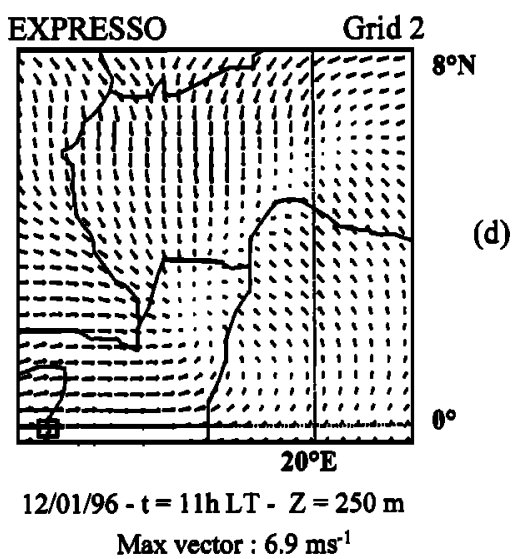

Figure 9. (a) Vertical meridian cross section of the $v$ component in grid 2 centered at Bangui. HF denotes Harmattan flow, and MF denotes Monsoon flow. (b) Vertical zonal cross section of the $u$ component in grid 2 at $Y=45$ close to high topography. ( $c$ and d) Wind vector in grid 2 for November 25 and December 1 at 1200 UTC.

spatial tracks in grid 2 for both cases (Figure 13). We get five flights above forest and three above savanna because flight 53 is above savanna and forest as well. Flights were planned between 1100 and 1300 (local time), the period of maximum radiation and fully developed boundary layer. These flights included profiles and legs with departure and return to Bangui. We note that the flights are far from emission sources, except for flight 51 above savanna (Figures 5 and 13). In Figure 13 the surface ITCZ is reported. Although these flights cover only a small part of central Africa, they characterize the air masses located south of the ITCZ for the first event and near the ITCZ for the second event. The observed air masses represent a domain of about $300 \mathrm{~km} \times 300 \mathrm{~km}$.

\section{Redistribution of Carbon Monoxide Over Central Africa}

The redistribution of pollutants emitted by biomass burning in savanna regions over central Africa is difficult to simulate because of the recirculations. In this work we investigate the redistribution of an inert tracer: carbon monoxide $\mathrm{CO}$, which has a lifetime of 1 month.

\subsection{Comparisons With Observations}

As stated in section 2, the emitted CO mass depends on burnt areas which are very variable day by day. We said that estimates of $\mathrm{CO}$ emissions are certainly not very accurate on a daily basis, but must be quite reliable when cumulated over several days ( 4 or 5 days). Figure 3 shows this apparent variability. During the first couple of days of the first event, the emissions are weak, but on the third day (November 25), they are very intense, reaching $144 \mathrm{~kg} \mathrm{ha}^{-1} \mathrm{~d}^{-1}$ (Figure 5); for the second event, they decrease every day.

For this reason, we compare observed and modeled values only at the end of each event. The corresponding flights are flight 47 (first event) and flight 53 (second event). It is a tough problem because of the difficulty of $\mathrm{CO}$ source assessment, and also because of the accumulation of small errors in wind fields on successive days.

Figure 14 displays these comparisons between modeled and measured $\mathrm{CO}$ concentrations for both events.

Flight 47 (first event) consists of an horizontal leg at $500 \mathrm{~m}$ above ground level (up to $5500 \mathrm{~s}$ ) over forest far from sources, then a northward ascent (up to $3500 \mathrm{~m}$ ) toward the polluted zone, and finally a descent to $2000 \mathrm{~m}$. During the first leg the model shows background values $(200 \mathrm{ppb})$ for both runs $A$ and $B$, whereas the measured values are much greater (300 ppb). During the ascending northward leg, closer to source zones, the agreement is much better, but only for run B. The same remark applies for the last descending leg. Flight 53 (second event) is almost meridian: a first leg southward above forest 


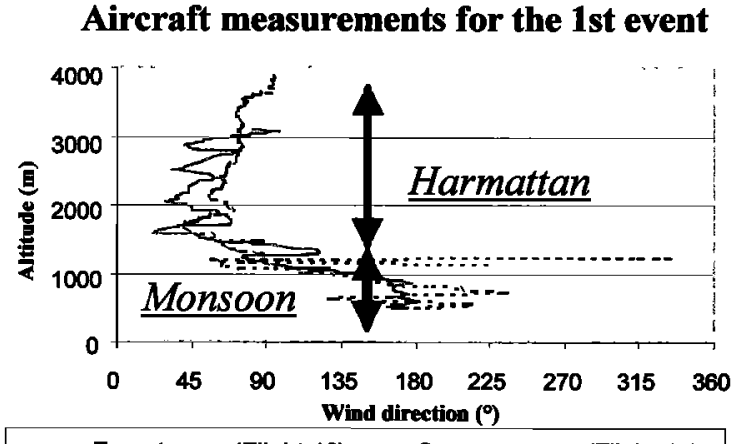

........ Forest zone (Flight 46)___ Savanna zone (Flight 45)

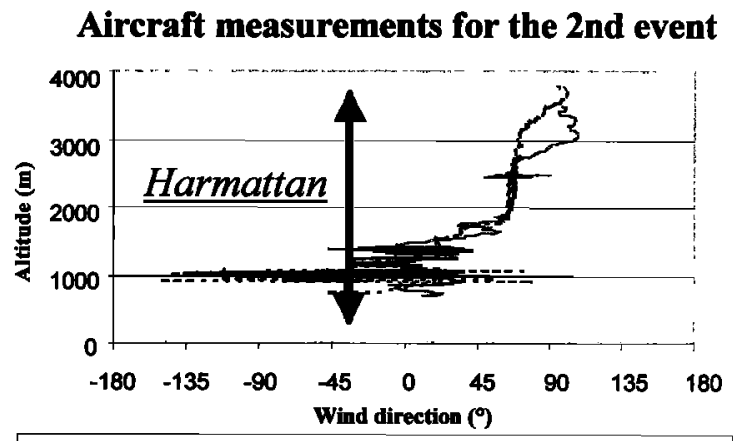

$\cdots$ Forest zone (Flight 52) - Savanna zone (Flight 51)
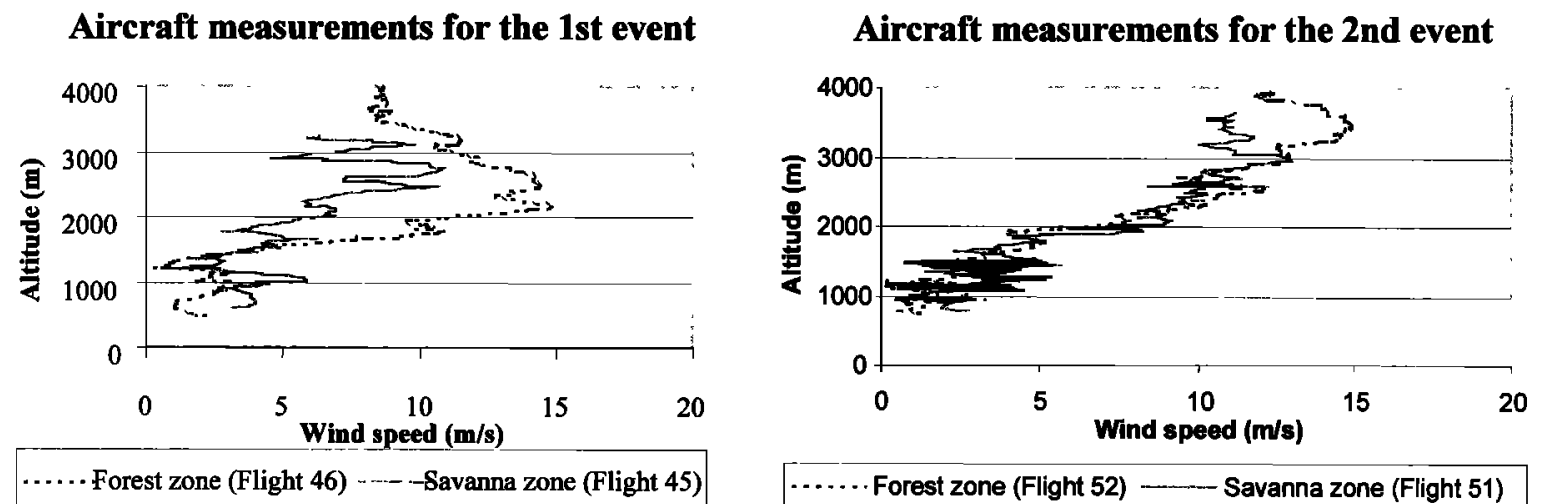

Figure 10. Profiles of wind in the EXPRESSO campaign for flights 45 and 46 on November 24 and 25 and for flights 51 and 52 on November 30 and December 1.

(about $3800 \mathrm{~s}$ ), a second leg northward (over forest, then savanna). The flight is continually descending from $2000 \mathrm{~m}$ above ground level to about $500 \mathrm{~m}$. Run $\mathrm{A}$ is not realistic at all (severe overestimations). The values from run $\mathbf{B}$ are much more satisfactory, although they are greater than observations in the first leg. During the second leg, the modeled values from run B become increasingly satisfactory, and particularly near the surface. In its entirety, the values obtained from run $B$ are more accurate than those from run $\mathrm{A}$.

Figure 15a shows two CO profiles from the flights 45 and 46 (November 24 and 25, 1996) of the EXPRESSO campaign: the first for the savanna zone and the second for the forest zone. Figure 15b exhibits the corresponding simulated $\mathrm{CO}$ profiles obtained from runs $\mathrm{A}$ and $\mathrm{B}$. For run $\mathrm{B}$, the two methods (CV
EXPRESSO

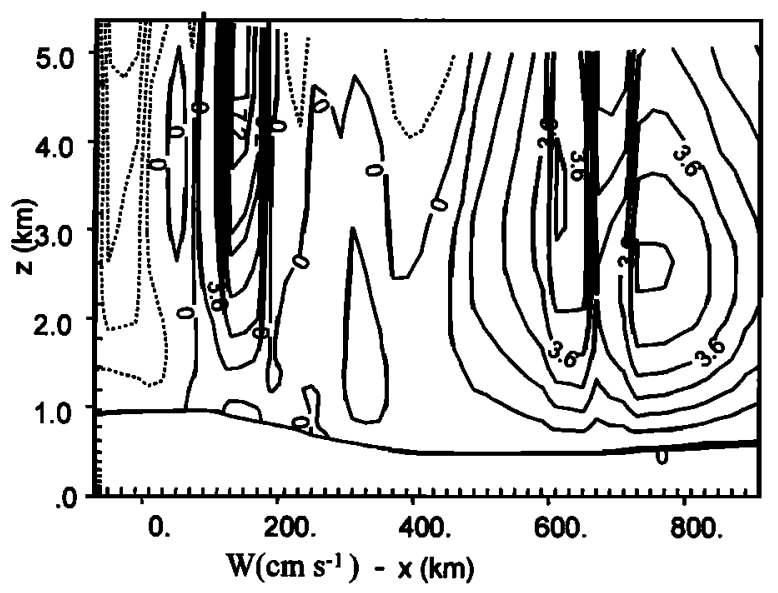

(a)
EXPRESSO

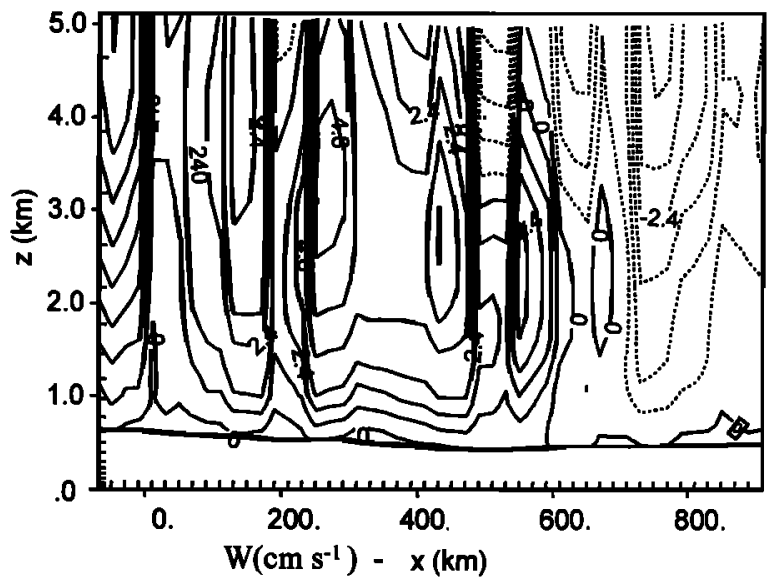

(b)

Figure 11. Vertical cross section of ascent speed $\left(\mathrm{cm} \mathrm{s}^{-1}\right)$ in grid 2 (a) close to high topography, $Y=45$ and (b) at the middle, $Y=25$. 


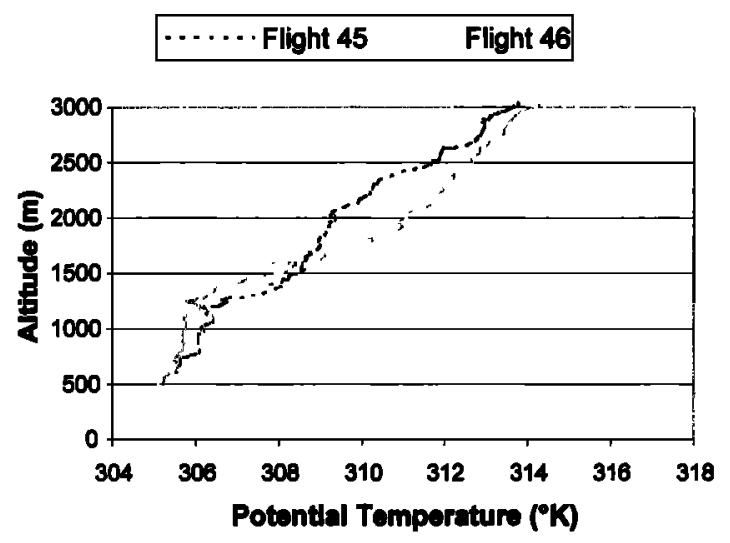

Aircraft measurements

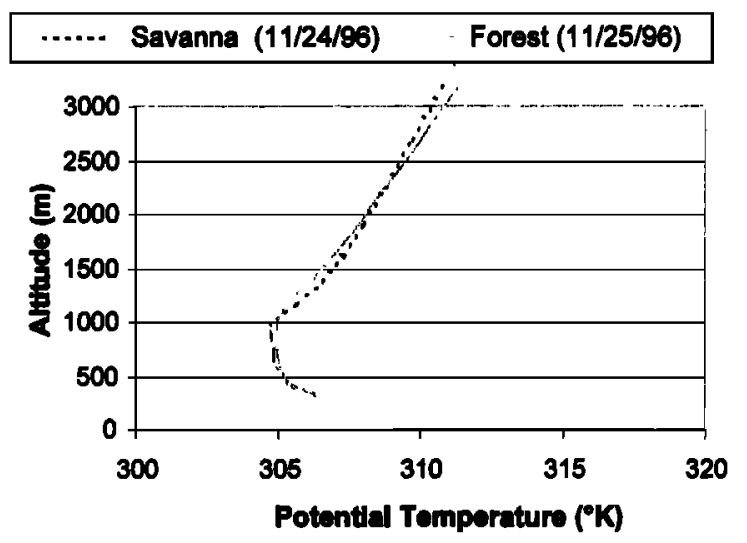

Numerical results

Figure 12. Potential temperature simulated and measured near Bangui (Guinean savanna) (dashed line) and inside the forest zone (solid line).

or NPP) are performed. In both cases (savanna or forest), run $A$ overestimates the $C O$ concentration values, and for run $B$ the values obtained from the method of NPP are higher (about $30 \%$ ) than for CV. In savanna the modeled profile has a maximum in agreement with observation for the value, but the position is lower. For the forest zone, below $1000 \mathrm{~m}$, inside the boundary layer, we have abnormally high $\mathrm{CO}$ concentrations (greater than $250 \mathrm{ppb}$ ), which shows that the complex dynamical situation can lead to the transport of the pyrogenic emission within the forest, inside Monsoon flow. Entrainment at the top of the forest boundary layer also contributes strongly to increase the pollution in this a priori undisturbed area (C. Delon et al., unpublished manuscript, 1999). The model results show that the two maxima of $\mathrm{CO}$ concentration (350$450 \mathrm{ppb}$ ) at $1000 \mathrm{~m}$ and $2500 \mathrm{~m}$ are due to the motion of the compounds emitted by bush fires located in the Central African Republic and in Cameroon where active fires are very important (Figure 5a).

\subsection{Numerical Results}

As explained above, we examine only the last two days of each event.

7.2.1. First event. We first focus on meridian movements $\left(18^{\circ} \mathrm{E}\right.$ ). In Figure 16 we see that on November 25 (day 3, Figure 16a) the pollutants remain near surface because of the atmospheric stability and wind weakness in the Monsoon flow. The ITCZ acts as a dynamical barrier and precludes any southward exchange. In contrast, on November 26 (day 4, Figure 16b) the blockings have been overcome: convergences associated with the ITCZ induce a strong vertical transport, whereas a nonnegligible southward horizontal transfer from savanna to forest zone is observed. As regards zonal $\left(4^{\circ} \mathrm{N}\right)$ movements (Figure 17), we note that on November 25 the vertical exchanges were not quite zero, as a weak and narrow vertical plume exists around abscissa $300 \mathrm{~km}$ (Figure 17a), which corresponds to $16^{\circ} \mathrm{E}$ (and therefore could not be detected in Figure 16a). On
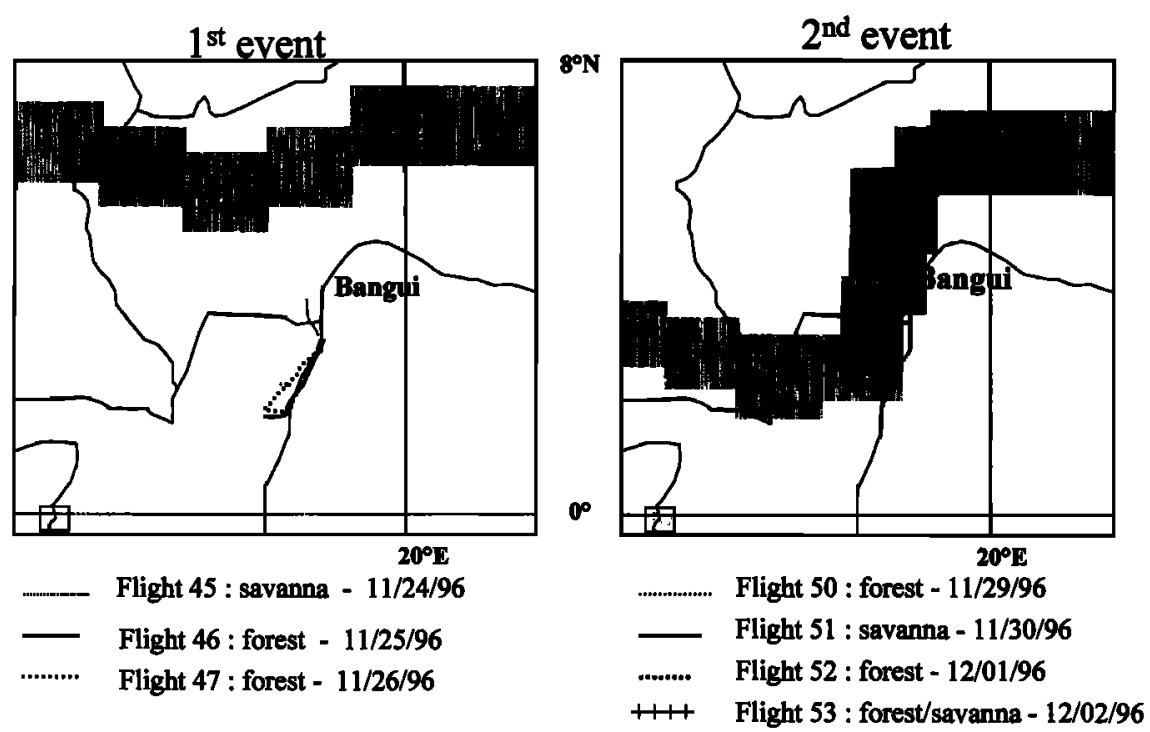

Figure 13. Aircraft tracks in grid 2. Shading denotes position of the ITCZ. 

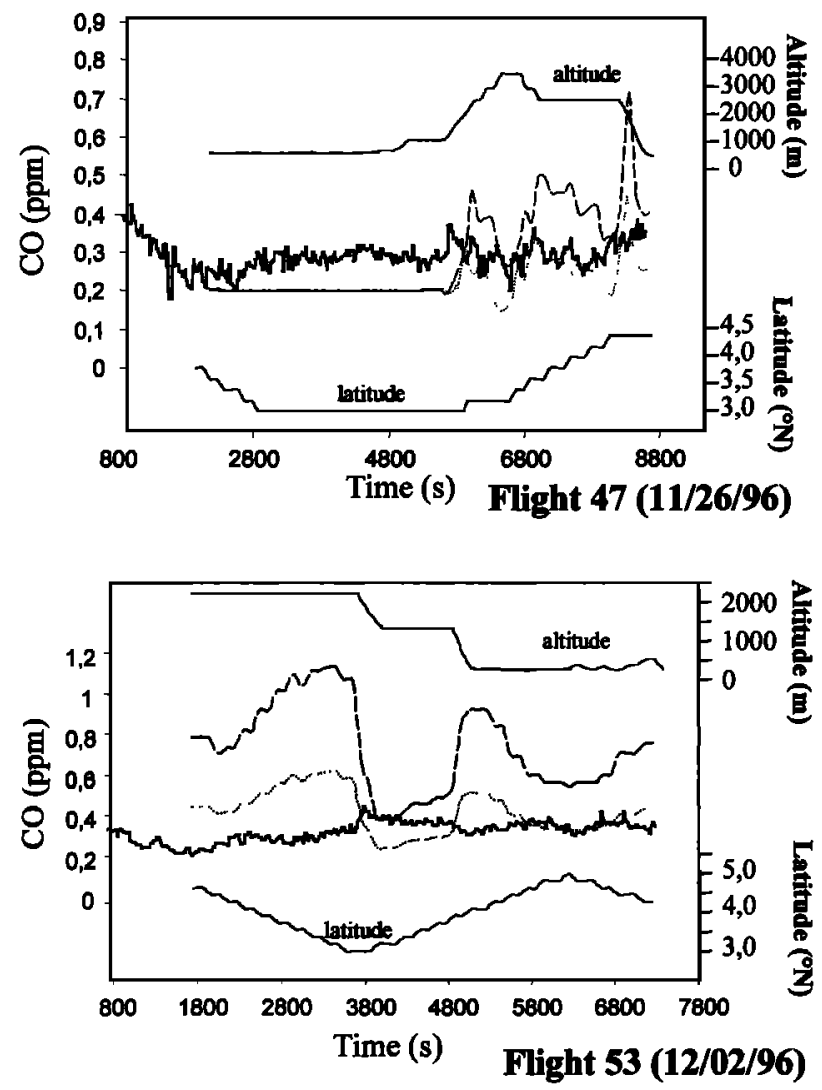

Figure 14. Detailed comparisons of model and observations for (top) flight 47 (over forest, November 26, 1996) and (bottom) flight 53 (over forest and savanna, December 2, 1996). Solid line denotes aircraft observation of $\mathrm{CO}$, dotted line denotes modeled $\mathrm{CO}$ from run $\mathrm{B}$, and dot-dashed line denotes modeled CO from run A.

November 26 the vertical transport between the boundary layer and the free troposphere extends to a large fraction of grid 2, that is, $\pm 200 \mathrm{~km}$ around the surface ITCZ. The transfers are well organized in the vertical and toward the west as well, and the associated concentrations are quite high. We note, however, that vertical transport is generally very weak except in the convergence zones due to the ITCZ or topography. We note also that the horizontal transport becomes important above the boundary layer and is mainly governed by the Harmattan flow.

At a larger scale, in grid 1 (Figures 18a and 18c), the horizontal fields in $\mathrm{CO}$ concentration at $1100 \mathrm{~m}$ above surface (upper limit of the boundary layer) exhibit very high concentrations (maximum equal to $1020 \mathrm{ppb}$ from the $\mathrm{CV}$ method and $1190 \mathrm{ppb}$ from the NPP method) near fires (central Cameroon and central Africa), whereas far from fires (around 300 $\mathrm{km}$ ), the CO concentration remains weaker, about 250-300 $\mathrm{ppb}$. We conclude that in the boundary layer the maximum of $\mathrm{CO}$ is closely linked to maximum emission (central Cameroon) and the polluted area spreads mainly in the zonal direction. Above the boundary layer, at $2000 \mathrm{~m}$ (Figures 18d and 18f), the maxima are always over central Cameroon, and the $\mathrm{CO}$ distribution is located above $3^{\circ} \mathrm{N}$ in latitude due to recirculations (Figure 18e) over central Cameroon and the Central African Republic, with values around 250-350 ppb. In Figures 18e and 18f the maxima obtained from the two methods are nearly the same (570 and $630 \mathrm{ppb}$ ).

We note that during this event the structure of the $\mathrm{CO}$ plume, some peaks (maxima $\mathrm{CO}$ concentrations) with strong gradients in their immediate surroundings, is not qualitatively modified during the transport. This feature originates from the wind weakness at any level (Figures $18 \mathrm{~b}$ and 18e) over the fire zone (Cameroon and east of the Central African Republic). The transfer between the boundary layer and the free troposphere is not horizontally uniform. It depends on ascents associated with local circulations, but in this case the plume does not spread to the south below $3^{\circ} \mathrm{N}$.

7.2.2. Second event. For this event (Figure 19), on December 1 , even though the emissions are located in the Central African Republic or Sudan, we note that at $1100 \mathrm{~m}$ above the surface (Figure 19a), the plume spreads up to the equator above the forest zone and follows the southward shift of the ITCZ. We note a maximum south of the Central African Republic, but no pollutant over Cameroon: The emissions are negligible in this region and the wind is oriented southward (Figure 19d). At $2000 \mathrm{~m}$ (Figure 19a) the CO plume has the same pattern as at $1100 \mathrm{~m}$. On December 2 (Figure 19c), the plume spreads over all of central Africa. The wind fields (Figures 19e and 19f) have the same pattern at both levels. They bring out pollutants from far away from the equator to the Southern Hemisphere.

\section{Discussion}

The EXPRESSO campaign raised many questions about the CO concentration. Let us limit these to two "abnormal" features. First, high concentrations (greater than $250 \mathrm{ppb}$ ) in the forest zone have been observed (a value which is much greater than expected). Second, inside the boundary layer, there are very small differences in $\mathrm{CO}$ concentration between forest and Guinean savanna regions even though the latter would be more polluted than the former. A tentative explanation of both phenomena could be the following. In central Africa the biomass burns at the beginning of the dry season. During this period the surface ITCZ is either high in latitude $\left(7^{\circ}-8^{\circ} \mathrm{N}\right)$ as for the first event, or lower $\left(4^{\circ}-6^{\circ} \mathrm{N}\right)$ as for the second event. The emission maps (Figures $5 \mathrm{a}$ and $5 \mathrm{~b}$ ) point out that many fires are located inside the Monsoon flow, below $8^{\circ} \mathrm{N}$ as for the first event or even below $6^{\circ} \mathrm{N}$ as for the second event. Hence many burnt areas are located in Guinean savanna, within the Monsoon flow. The gases emitted in these zones move slowly toward the southern forest zone and stay near ground. They may be lifted when local circulations result in convergence zones (Figures 11, 16, and 17), so that the transfer between the boundary layer and the free troposphere is not systematic. Consequently, the emitted gases are only partly transferred to the Harmattan flow above boundary layer. Then, the forest region is polluted (Figure 16) by the gases which stay near ground, and by entrainment processes which reinject the pollutants from the free troposphere into the forest boundary layer. Above the boundary layer an effective transport of the pollutants is possible, and they can cover a very long distance up to the Southern Hemisphere (Figures 19b and 19c). Cros et al. [1992] report observations over Congo of ozone plumes originating from central Africa fires.

The ITCZ cannot completely block the transport of pollutants toward the south, because its surface line is continuously moving (Figures 7 and 8 ) and fires may be found in Monsoon 

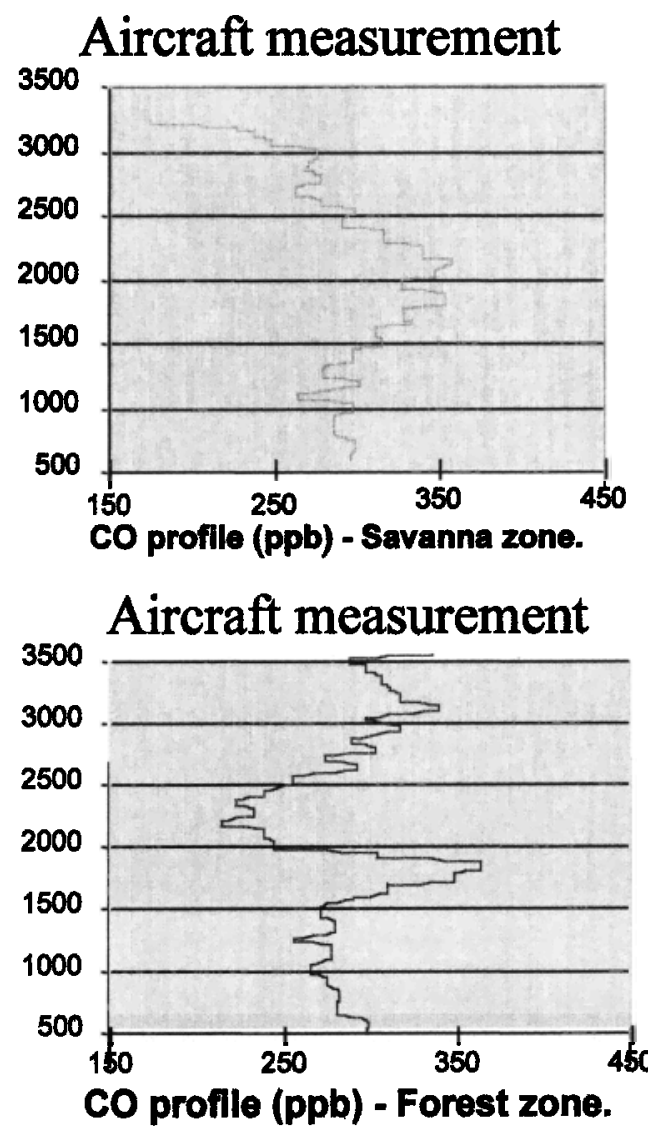

(a)

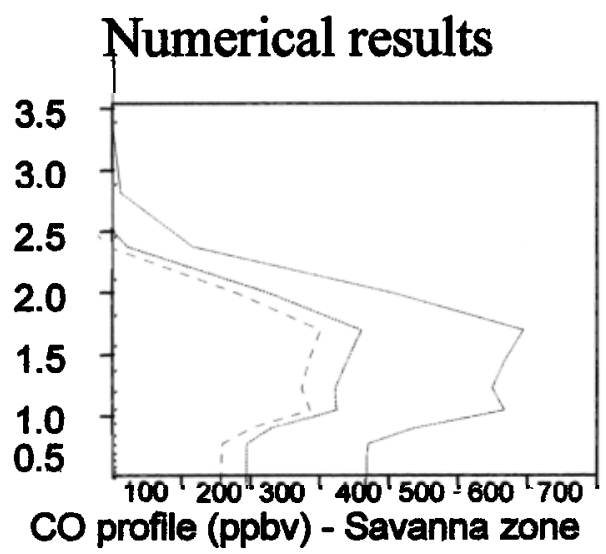

Numerical results

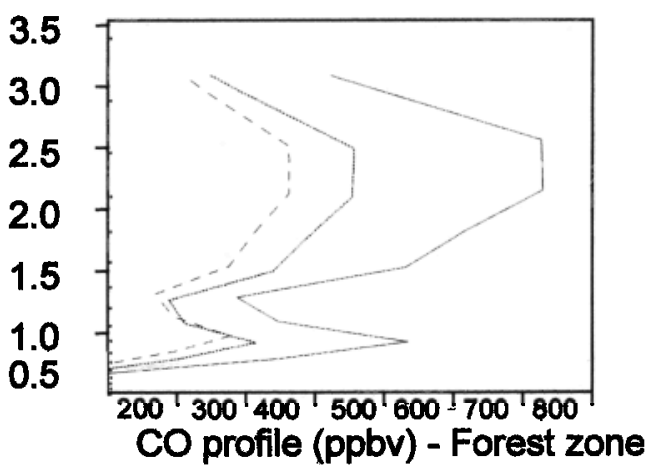

(b)

Figure 15. CO concentration profiles measured near Bangui (Guinean savanna) from flight 45 and in forest from flight 46. CO concentration profiles simulated are as follows: solid line denotes profiles from run A, dotted line denotes profiles from run B and the NPP method, and dashed line denotes profiles from run B and the CV method.



(a)

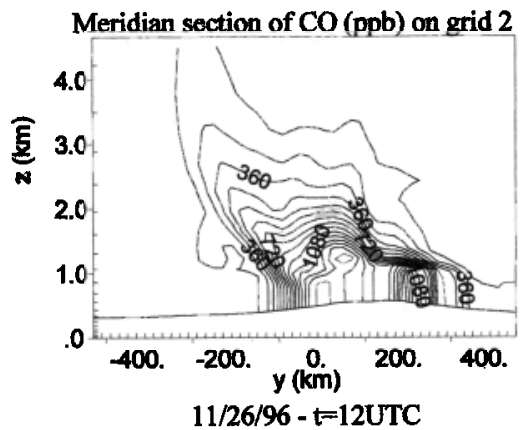

(b)

Figure 16. Vertical cross section of meridian CO concentration from run B and the CV method, at the middle of the grid 2 on (a) November 25 and (b) November 26, 1996. 




(a)
Zonal section of $\mathrm{CO}(\mathrm{ppb})$ on the grid 2

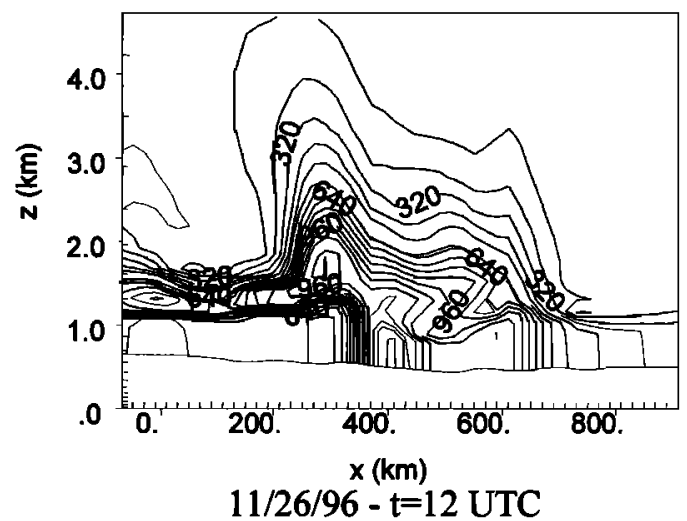

(b)

Figure 17. Vertical cross section of zonal CO concentration from run B and the CV method, at the middle of the grid 2 on (a) November 25 and (b) November 26, 1996.

flow, in Guinean savanna, or even forest regions. The synoptic meteorology conditions are different from these of west Africa where the ITCZ is a barrier for the transfer of biomass burning compounds [Edy and Cautenet, 1998].

Moreover, we can mention that high $\mathrm{CO}$ concentrations (2 ppm) have been modeled near fires; these values are realistic, because they are confirmed by measurements during the SAFARI campaign [Le Canut et al., 1996].

Our main aim was to test the capability of the mesoscale model coupled with a $\mathrm{CO}$ emission module to retrieve the fields of redistributed $\mathrm{CO}$. To evaluate the surface fluxes emitted by fires, we first estimate the biomaterial cover from either of two independent methods, which we have named $\mathrm{CV}$ and
NPP. Next, the CO fluxes are calculated from (1). Use of this equation in the model leads to a good order of magnitude in CO concentration after calibration of the constant $\alpha$. Under this condition the comparisons show that the numerical results from run $B$ and the aircraft measurements are in relatively good agreement for two tracks (Figure 14) and for two profiles (Figure 15). The global shapes of modeled vertical CO profiles are quite similar to experimental ones (agreement for the maxima and minima), and the numerical values fit fairly well (within an error range of about $30 \%$ ). On the other hand, in view of these uncertainties, it is not possible to decide which of the two methods for biomass assessment, CV or NPP, is the best, because they differ by $30 \%$ in vegetation cover. Never- (a)

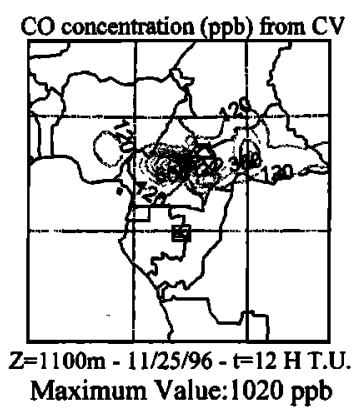

(b)

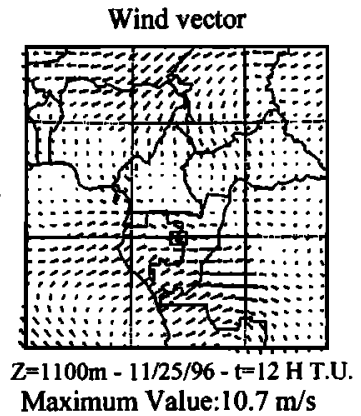

(c)

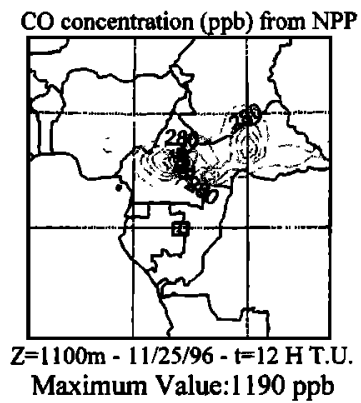



(e)

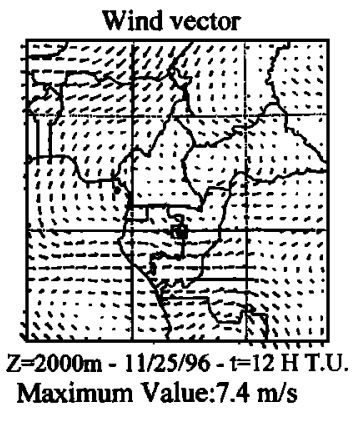



Figure 18. Horizontal cross section of $\mathrm{CO}$ concentration from the CV and NPP methods, and winds at 1100 and $2000 \mathrm{~m}$ in grid 1 for the first event. 

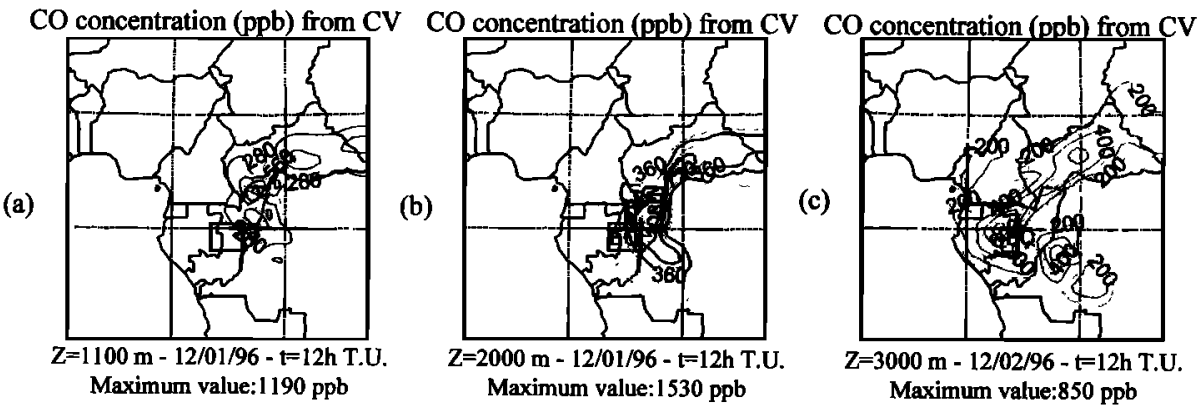

(d)

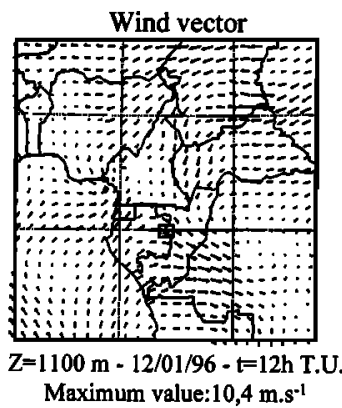

(e)

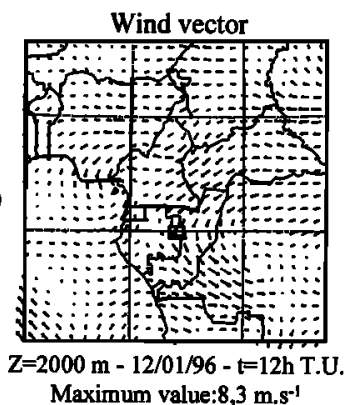

Wind vector

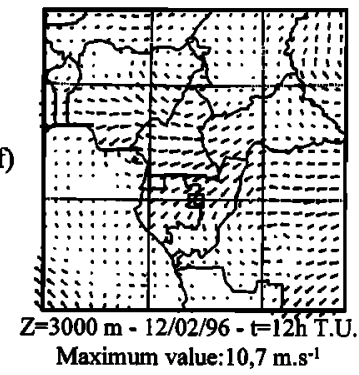

Figure 19. Horizontal cross section of $C O$ concentration from the $C V$ method, and winds at 1100,2000 , and $3000 \mathrm{~m}$ in grid 1 for the second event.

theless, we can justify that run $B$ is better run $A$, from which we infer the value of the combustion factor $\alpha$, which we take here equal to 0.4. Even though this value is derived from a tuning procedure, it may be justified because the period under study is the beginning of the dry season, so that the surface wetness precludes a complete burning. This preliminary mesoscale study, including a realistic estimation of sources, contributes to the knowledge of the amount of liberated gases by fires, although we cannot claim to give exact values in the present state of our work.

\section{Summary and Conclusions}

The comprehensive mesoscale model (RAMS) allowed us to retrieve the meteorological fields measured during the EXPRESSO campaign. The positions of the bush fires by the NOAA AVHRR images and the knowledge of biomass density give an estimate of emitted $\mathrm{CO}$ fluxes using (1). Two runs are performed corresponding to values of the $\mathrm{CO}$ flux with the combustion factor $(\alpha)$ equal to $80 \%$ for run $\mathrm{A}$ and $40 \%$ for run B. In addition, for run B, biomaterial is assessed from two independent methods: classification of vegetation formations (CV) and net primary productivity (NPP). Two fire events of 4 and 5 days have been simulated. During this period of experiment, aircraft observations over forest and savanna regions were available and the $\mathrm{CO}$ emissions were very different day by day.

In central Africa the biomass burning period takes place in the beginning of the dry season and the ITCZ position moves in latitude $\left(7^{\circ}-8^{\circ} \mathrm{N}\right.$ for the first event and $4^{\circ}-6^{\circ} \mathrm{N}$ for the second event). The trace gases emitted by fires in the boundary layer stay near the surface in these regions of weak winds and are brought up to the free troposphere in the areas with convergence zones due to the ITCZ or topography. CO concentrations of $250-350 \mathrm{ppb}$ are found in the forest zone, in spite of the distance from the fires (around $300 \mathrm{~km}$ ). An effective transport is possible when the pollutants reach the free tropo- sphere, where they can cover a very long distance (about 1000 $\mathrm{km}$ in 4 days). Pollutants may then be reinjected into the forest boundary layer by entrainment processes. In this study we show that the main mechanisms of the chemical species spatial redistribution originated from mesoscale features.

The aircraft measurements in the forest and savanna regions (profiles or horizontal legs) are in rather good agreement with the numerical results from run $B$ for the two events, where synoptic meteorological situations are different. The difference between the $\mathrm{CO}$ simulated fields obtained from (CV) or (NPP) is weak (about $20-30 \%$ ), and it is difficult to discriminate the best method because this difference is generally less than the gap between model and observations. Nevertheless, the NPP method overestimates the CO flux by $30 \%$ as compared to the CV approach. Finally, the combustion factor $(\alpha)$ is derived from an adjustment procedure, and its value is 0.4 .

This work has been led by a comprehensive methodology because every step is critically investigated: biomaterial cover, burnt areas, released gases, and dynamics with mesoscale modeling. Thus this preliminary numerical method enabled us not only to provide a correction of the estimated $\mathrm{CO}$ fluxes from savanna fires in central Africa, but also to improve the knowledge of the amount of liberated gases by fires. In the future we want to apply this method, by taking photochemistry into account, to all trace gases which have a significant impact on a regional scale, such as ozone.

Acknowledgments. This modeling study is supported by funding of the French Centre National de la Recherche Scientifique (Programme National de Chimie Atmosphérique). This work makes extensive use of the RAMS model, which was developed under the support of the National Science Foundation (NSF) and the Army Research Office (ARO). Computer resources were provided by IDRIS (Institut du Développement et des Ressources en Informatique Scientifique) project 721 . The authors also wish to thank the computer team of the Laboratoire de Météorologie Physique de l'Université Blaise Pascal (France): R. Pejoux, A. M. Lanquette, and F. Besserve. 


\section{References}

Andreae, M. O., Biomass burning: Its history, use, and distribution and impact on environmental quality and global climate, in Global Biomass Burning: Atmospheric, Climatic, and Biospheric Implications, edited by J. S. Levine, pp. 3-21, MIT Press, Cambridge, Mass., 1991.

Andreae, M. O., E. Atlas, H. Cachier, W. R. Coffer III, G. W. Harris, G. Helas, R. Koppmann, J. P. Lacaux, and D. E. Ward, Trace gas and aerosol emissions from savanna fires, in Biomass Burning and Global Change, edited by J. S. Levine, pp. 278-295, MIT Press, Cambridge, Mass., 1996a.

Andreae, M. O., E. Atlas, G. W. Harris, G. Helas, A. de Kock, R. Koppmann, W. Maenhaut, S. Mano, W. H. Pollock, J. Rudolph, D. Scharffe, G. Schebeske, and M. Welling, Methyl halide emissions from savanna fires in southern Africa, J. Geophys. Res., 101, 23,603$23,613,1996 \mathrm{~b}$.

Avissar, R., and R. A. Pielke, A parameterization of heterogeneous land surfaces for atmospheric numerical models and its impact on regional meteorology, Mon. Weather Rev., 117, 2113-2136, 1989.

Browell, E. V., et al., Ozone and aerosol distributions and air mass characteristics over the South Atlantic basin during the burning season, J. Geophys. Res., 101, 24,043-24,068, 1996.

Brown, S., and G. Gaston, Estimates of biomass density for tropical forests, in Biomass Burning and Global Change, vol. 1, Remote Sensing, Modeling and Inventory Development, and Biomass Burning in Africa, edited by J. S. Levine, pp. 133-139, MIT Press, Cambridge, Mass., 1996.

Chatfield, R. B., J. A. Vastano, H. B. Singh, and G. Sachse, A general model of how fire emissions and chemistry produce African/oceanic plumes $\left(\mathrm{O}_{3}, \mathrm{CO}, \mathrm{PAN}\right.$, smoke $)$, J. Geophys. Res., 101, 24,279-24,306, 1996.

Chen, C., and W. R. Cotton, The sensitivity of a simulated extratropical mesoscale convective system to longwave radiation and ice-phase microphysics, J. Atmos. Sci., 45, 3897-3910, 1988.

Clark, T. L., and R. D. Farley, Severe downslope windstorm calculations in two and three spatial dimensions using the anelastic interactive grid nesting: A possible mechanism for gustiness, J. Atmos. Sci., 41, 329-350, 1984.

Cofer, W. R., III, J. S. Levine, E. L. Winstead, and B. J. Stocks, Gaseous emissions from Canadian boreal forest fires, Atmos. Environ., Part A, 24, 1653-1629, 1990.

Cofer, W. R., III, J. S. Levine, E. L. Winstead, D. R. Cahoon, D. I. Sebacher, J. P. Pinto, and B. J. Stocks, Source compositions of traces gases released during African savanna fires, J. Geophys. Res., 101, 23,597-23,602, 1996.

Cros, B., D. Nganga, A. Minga, J. Fishman, and V. Brackett, Distribution of tropospheric ozone at Brazaville, Congo, determined from ozonesonde measurements, J. Geophys. Res., 97, 12,869-12,875, 1992.

Crutzen, P. J., and M. O. Andreae, Biomass burning in the tropics: Impacts on atmospheric chemistry and biogeochemical cycles, Sciences, 250, 1669-1778, 1990.

Davies, H. C., A lateral boundary formulation for a multi-level prediction model, Tellus, 102, 405-418, 1976.

Delmas, R. A., P. Loudjanni, A. Polaire, and J. C. Menaut, Biomass burning in Africa: An assessment of annually burnt biomass, in Global Biomass Burning: Atmospheric, Climatic, and Biospheric Implications, edited by J. S. Levine, pp. 126-132, MIT Press, Cambridge, Mass., 1991.

Delmas, R. A., J. P. Lacaux, J. C. Menaut, L. Abbadie, X. Le Roux, $G$. Helas, and G. Lobert, Nitrogen compound emission from biomass burning in tropical African savanna, FOS/DECAFE 91 Experiment (Lamto, Ivory Coast), J. Atmos. Chem., 22, 175-194, 1995.

Delmas, R. A., et al., Experiment for Regional Sources and Sinks of Oxidants (EXPRESSO): An overview. J. Geophys. Res., this issue.

Edy, J., and S. Cautenet, Biomass burning: Local and regional redistributions, in Air Pollution Modeling and Its Application, pp. 63-69, Plenum, New York, 1998.

Fishman, J., C. E. Watson, J. C. Larsen, and J. A. Logan, Distribution of tropospheric ozone determined from satellite data, J. Geophys. Res., 95, 3599-3617, 1990.

Fishman, J., V. G. Brackett, and K. Fakhruzzaman, Distribution of tropospheric ozone in the tropics from satellite and ozonesonde measurements, J. Atmos. Terr. Phys., 54, 589-597, 1992.

Fishman, J., V. G. Brackett, E. V. Browell, and W. B. Grant, Tropospheric ozone derived from TOMS/SBUV measurements during TRACE A, J. Geophys. Res., 101, 24,069-24,082, 1996.
Flasse, S. P., and P. Ceccato, A contextual algorithm for AVHRR fire detection, Int. J. Remote Sens., 17(2), 419-424, 1996.

Garstang, M., P. D. Tyson, R. Swap, M. Edwards, P. Kallberg, and J. A. Lindesay, Horizontal and vertical transport of air over southern Africa, J. Geophys. Res., 101, 23,721-23,726, 1996.

Grégoire, J-M., S. Pinnock, E. Dwyer, and E. Janodet, Satellite monitoring of vegetation fires for EXPRESSO: Outline of activity and relative importance of the study area in the global picture of biomass burning, J. Geophys. Res., this issue.

Heimann, M., and C. D. Keeling, A three dimensional model of atmospheric $\mathrm{CO}_{2}$ transport based on observed winds, 2, Model description and simulated tracer experiments, in Aspects of Climate Variability in the Pacific and the Western Americas, edited by D. $\mathrm{H}$. Peterson, Geophys. Monogr. Ser., vol. 55, pp. 237-275, AGU, Washington, D. C., 1989.

Hurst, D. F., D. W. T. Griffith, J. N. Carras, D. J. Williams, and P. J. Fraser, Measurements of trace gases emitted by Australian savanna fires during the 1990 dry season, J. Atmos. Chem., 18, 33-56, 1994a. Hurst, D. F., D. W. T. Griffith, and G. D. Cook, Trace gas emissions from biomass burning in tropical Australian savannas, J. Geophys. Res., 99, 16,441-16,456, 1994b.

Janodet, E., A. Tournier, S. Brownlee, B. Glénat, and J.-M. Grégoire, Software package developed and implemented by MTV-SAI for the pre-processing and processing of NOAA-AVHRR images acquired with a portable receiving station, JRC Tech. Note I.96.245, 32 pp., Jt. Res. Cent., Ispra, Italy, Dec. 1996.

Koppmann, R., A. Khedim, J. Rudolph, G. Helas, M. Welling, and T. Zenker, Airborne measurements of organic trace gases from savanna fires in southern Africa during SAFARI 92, in Biomass Burning and Global Change, vol. 1, Remote Sensing, Modeling and Inventory Development, and Biomass Burning in the Boreal Forest, edited by J. S. Levine, pp. 309-319, MIT Press, Cambridge, Mass., 1996.

Krishnamurti, T. N., M. C. Sinha, M. Kanamitsu, D. Oosterhof, H. Fuelberg, R. Chatfield, D. J. Jacob, and J. Logan, Passive tracer transports relevant to the TRACE A experiment, J. Geophys. Res., 101, 23,889-23,909, 1996.

Kumar, M., and J. L. Monteith, Remote sensing of crop growth, in Plants and the Daylight Spectrum, edited by H. Smith, pp. 133-144, Academic, San Diego, Calif., 1982.

Lacaux, J. P., H. Cachier, and R. A. Delmas, Biomass burning in Africa: An overview of its impact on atmosphere chemistry, in Fire in the Environment: The Ecological, Atmospheric and Climatic Importance of Vegetation Fires, edited by P. J. Crutzen and J. Goldammer, pp. 159-191, John Wiley, New York, 1993.

Lacaux, J. P., J. M. Brustet, R. A. Delmas, J. C. Menaut, L. Abbadie, R. Bonsang, H. Cachier, J. G. R. Baudet, M. O. Andreae, and G. Helas, Biomass burning in the tropical savannas of Ivory Coast: An overview of the field experiment Fire of Savannas (FOS/ DECAFE 91), J. Atmos. Chem., 22, 195-216, 1995.

Le Canut, P., M. O. Andreae, G. H. Harris, F. G. Wienhold, and T. Zenker, Airborne studies of emissions from savanna fires in southern Africa, 1, Aerosol emissions measured with a laser optical particle counter, J. Geophys. Res., 101, 23,615-23,630, 1996.

Levine, J. S., Introduction, in Global Biomass Burning: Atmospheric, Climatic, and Biospheric Implications, edited by J. S. Levine, pp. 25-30, MIT Press, Cambridge, Mass., 1991.

Lobert, J. M., D. H. Scharffe, W. M. Hao, T. A. Kuhlbusch, R. Seuwen, P. Warneck, and P. J. Crutzen, Experimental evaluation of biomass burning emissions: Nitrogen carbon containing compounds, in Global Bımass Burning: Atmospheric, Climatic, and Biospheric Implications, edited by J. S. Levine, pp. 289-304, MIT Press, Cambridge, Mass., 1991.

Lyons, A. W., C. J. Tremback, and R. A. Pielke, Applications of the regional atmospheric systems (RAMS) to provide input to photochemical grid models for the Lake Michigan Ozone Study (LMOS), J. Appl. Meteorol., 34, 1762-1785, 1995.

Menaut, J. C., L. Abbadie, F. Lavenu, P. Loudjani, and A. Podaire, Biomass burning in west Africa savannas, in Global Biomass Burning: Atmospheric, Climatic, and Biospheric Implications, edited by J. S. Levine, pp. 133-142, MIT Press, Cambridge, Mass., 1991.

Menzel, W. P., E. C. Cutrim, and E. P. Prins, Geostationary satellite estimation of biomass burning in Amazonia during BASE-A, in Global Bıomass Burning: Atmospheric, Climatic, and Biospheric Implications, edited by J. S. Levine, pp. 41-46, MIT Press, Cambridge, Mass., 1991. 
Millan, M. M., R. Salvador, E. Mantilla, and G. Kallos, Photooxidant dynamics in the Mediterranean basin in summer: Results from European research projects, J. Geophys. Res., 102, 8811-8823, 1997.

Moula, M., J. M. Brustet, and J. Fontan, Remote sensing modelisation approach for diurnal estimation of burnt biomass in the Central African Republic savanna, J. Atmos. Chem., 25, 1-19, 1996.

Pereira, J. M. C., A comparative evaluation of NOAA/AVHRR vegetation indices for burned surface detection and mapping, IEEE Trans. Geosci. Remote Sens., 37(1), 217-226, 1999.

Pereira, J. M. C., B. S. Pereira, P. Barbosa, and D. Stroppiana, M. J. P. Vasconcelos, and J.-M. Grégoire, Satellite monitoring of fire in the EXPRESSO study area during the $1996 \mathrm{dry}$ season experiment: Active fires, burnt area, and atmospheric emissions. J. Geophys. Res., this issue.

Pickering, K. E., A. M. Thompson, Y. Wang, W. K. Tao, D. P. McNamara, V. W. J. H. Kirchhoff, B. G. Heikes, G. W. Sachse, J. D. Brudshaw, G. L. Gregory, and D. R. Blake, Convective transport of biomass burning emissions over Brazil during TRACE A, J. Geophys. Res., 101, 23,993-24,012, 1996.

Pielke, R. A., W. R. Cotton, R. L. Walko, C. J. Tremback, M. E. Nicholls, M. D. Moran, D. A. Wesley, T. J. Lee, and J. H. Copeland, A comprehensive meteorogical modeling system-RAMS, Meteorol. Atmos. Phys., 49, 69-91, 1992.

Pinty, B., and M. M. Verstraete, GEMI: A non-linear index to monitor global vegetation from satellite, Vegetatio, 101, 15-20, 1992.

Ramanathan, V., R. J. Cicerone, H. B. Sing, and T. Keihl, Trace gases trends and their potential role in climate change, J. Geophys. Res., 90, 5547-5566, 1985.

Ruimy, A., B. Saugier, and G. Dedieu, Methodology for the estimation of terrestrial net primary production from remotely sensed data, $J$. Geophys. Res., 99, 5263-5283, 1994.

Rutherford, M. C., Primary production in South Africa, in Biogeography and Ecology of Southern Africa, pp. 621-659, Junk, The Hague, 1978.

Scholes, R. J., J. Kendall, and C. O. Justice, The quantity of biomass in southern Africa, J. Geophys. Res., 101, 23,667-23,676, 1996.

Shea, R. W., B. W. Shea, and J. B. Kauffman, Fuel biomass and combustion factors associated with fires in savanna ecosystems of South Africa and Zambia, J. Geophys. Res., 101, 23,551-23,568, 1996.

Stocks, B. J., B. W. van Wilgen, W. S. W. Trollope, D. J. McRae, J. A. Mason, F. Weirich, and A. L. F. Potgieter, Fuels and fire behavior dynamics on large savanna fires in Kruger National Park, South Africa, J. Geophys. Res., 101, 23,541-23,550, 1996.
Thompson, A. M., R. D. Diab, G. E. Bodeker, M. Zunckel, G. J. R. Coetzee, C. B. Archer, D. P. McNamara, K. E. Pickering, J. Combrink, J. Fishman, and D. Nganga, Ozone over southern Africa during SAFARI-92/TRACE A, J. Geophys. Res., 101, 23,793-23,808, 1996.

Tremback, C. J., and R. Kessler, A surface temperature and moisture parameterization for use in mesoscale numerical models, paper presented at Seventh AMS Conference on Numerical Weather Prediction, Am. Meteorol. Soc., Montreal, Que., Canada, 1985.

Tremback, C. J., J. Powell, W. R. Cotton, and R. A. Pielke, The forward in time upstream advection scheme: Extension to higher orders, Mon. Weather Rev., 115, 540-555, 1987.

Tripoli, G., and W. R. Cotton, The Colorado State University threedimensional cloud/mesoscale model, part I, General theoretical framework and sensitivity experiments, J. Rech. Atmos., 16, 185-220, 1982.

Trollope, W. S. W., L. A. Trollope, A. L. F. Potgieter, and N. Zambatis, SAFARI-92 characterization of biomass and fire behavior in the small experimental burns in the Kruger National Park, J. Geophys. Res., 101, 23,531-23,540, 1996.

Wang, Y., W. K. Tao, K. E. Pickering, A. M. Thompson, J. S. Kain, R. F. Adler, J. Simpson, P. R. Keehn, and G. S. Lai, Mesoscale model simulations of TRACE A and preliminary regional experiment for storm-scale operational and research meteorology convective systems and associated tracer transport, J. Geophys. Res., 101, $23,993-24,012,1996$.

O. Amram, S. Cherchali, and G. Flouzat, CESBIO, UMR Centre National d'Etudes Spatiales, Université Paul Sabatier, CNRS, Toulouse, France.

S. Cautenet and D. Poulet, Laboratoire de Météorologie Physique, 24 avenue des Landais, Aubière Cedex 63177, France. (e-mail: cautenet@opgc.univ-bpclermont.fr)

R. Delmas and C. Delon, LA/OMM, Université Paul Sabatier, CNRS, Toulouse, France.

J.-M. Grégoire, Global Vegetation Monitoring Unit, Space Applications Institute, Joint Research Centre, Ispra (VA) 21020, Italy.

J. M. Pereira, Instituto Superior de Agronomia, Universidade Tecnica de Lisboa, Tapada da Ajuda, 1300 Lisboa Codex P-1399, Portugal. (e-mail: JPereira@pinus.isa.utl.pt)

(Received December 15, 1998; revised June 3, 1999; accepted June 7, 1999.) 